\title{
Studies on use of some types of fertilizers and sesame oil in controlling thrips insect and obtain high quality garlic
}

\author{
EL-Anany A. M. A. ${ }^{1}$, T. G. Anany' ${ }^{1}$ E.A.M. Mousa² and Mona. I. Ammar² \\ ${ }^{1}$ Vegetable Res. Dept., Hort. Res. Inst., Agric. Res. Center, Dokki 12618, Giza, Egypt \\ ${ }^{2}$ Plant Protection Research Institute (PPRI), Agric. Res. Center (ARC), Dokki 12618, Giza, Egypt
}

Received: 30 Oct. 2020 / Accepted 10 Dec. 2020 / Publication date: 30 Dec. 2020

\begin{abstract}
Two field experiments were conducted at kaha Research Farm, Horticultural Research Institute, Egypt during the two agricultural season of 2018/2019 and 2019/2020 to study the effect of organic fertilizers (poultry manure) and sesame oil in controlling thrips insects and its effect on growth, yield and quality of garlic bulbs (Allium sativum L.) cv. Sids 40. Poultry manure application with spraying sesame oil extract showed a significant increase on most studied traits. The highest increment was observed with applying poultry manure plus $150 \mathrm{~kg}$ sulphur as fertilizer using sesame oil spray for all vegetative traits except fresh weight $\left(1^{\text {st }}\right.$ season), dry weight $\left(2^{\text {nd }}\right.$ season), chlorophyll (both seasons) in which marshal $25 \%$ insecticide was the highest one, in the same time, this treatment gave an increase significantly equal to the treatment that produced the highest value in all studied yield and its attributed traits as well as bulb chemical constituents. As the sulfur level increased from $75 \mathrm{~kg}$ to $150 \mathrm{~kg}$ (under all spraying treatments), $\mathrm{OF} \times \mathrm{BioC}$ interaction showed a significant increase in most studied traits. The population of thrips reached to a peak level 336 and 462 thrips/plant for mineral and organic fertilizers, respectively at $4^{\text {th }}$ week of March $\left(24^{\text {th }}\right.$ week after planting date). Then the thrips population fluctuated between increase and decrease till 200 (mineral fertilization) and 416 (organic fertilization) thrips/plant. Although, the organic and mineral fertilizers treated by chemical insecticide did not leave any insects on the plant $(100 \%$ reduction), the total yield of the organic treatment interacted with sesame oil (OFBioC) was significantly equal to yield of mineral or organic fertilizer interacted with chemical insecticide. It was also noticed that this treatment (OFBioC) significantly exceeded the bulb fresh weight and the number of cloves per plant, while it was significantly equal with both diameter and weight of garlic clove compared to the treatment of mineral fertilization plus the chemical insecticide. It is believed that this is due to the effect of the sesame oil (in manure treatment) as a catalyst and enhancer for the garlic plant in resisting the presence of the insect and reducing the harm or, on the other hand inhibiting the insect activity in causing any harm (rather than being an insecticide) confirming the role of sesame oil as an enhancer and/or antioxidant for garlic plant more than an effect on the thrips insect. Our results also suggested the bulb quality as an organic seeds were the main drivers of long-term our study.
\end{abstract}

Keywords: Garlic, Thrips tabaci, sesame oil, organic and mineral fertilizers, poultry manure

\section{Introduction}

Garlic is one of the most important vegetable crops in Egypt, and a popular crop as it is widely cultivated in Egypt and all over the world and is one of the most important export vegetable crops in Egypt desired in European markets and other countries in the world, due to its quality and good carry it for storage, as well as his appearance at a time when demand and severe need of markets too big to be, and so the prices, making it a profitable crop with a farm. The area cultivated with garlic in Egypt 2018/2019 season is about 38483 feddans, with a total production of 360113 ton/fed (Egyptian Ministry of Agriculture and Land Reclamation, 2019), as Egypt ranks among the garlic-producing countries after China, South Korea and India. Garlic is of great medicinal value in the prevention and treatment of many human diseases. Also, garlic has insecticidal and insect repellant properties (Adewale et al., 2011). In general fresh garlic consists of moisture $(62.8 \%)$, fat $(0.1 \%)$, fiber $(0.8 \%)$ and protein $(6.3 \%)$ and is a good source of carbohydrates, phosphorous, manganese, selenium, and vitamin C (Pamplona Roger, 2001). Garlic can grow in many types of land but it needs good nutrition in order to give a profitable return. The use of different fertilizers (type, time and rate) is one of the determining factors 
of garlic production that must be considered (Diriba-Shiferaw et al., 2013 and Shrestha et al., 2018). Nitrogen is one of the essential nutrients that contribute greatly to crop production and yield growth and productivity are highly dependent on the supply and proper management of $\mathrm{N}$ soil (Adhikari et al., 2016). It was found that nitrogen fertilizers are important in the production of bulbs, the components of the crop, the quality and the ability of storing the bulbs (El-Zohairi, 2003) for that addition of nitrogen fertilizers increases dry matter and productivity. The need for organic fertilization has become more than before because of its health or environmental benefits, however it has been widely used as alternative fertilizers for organically grown fields and can serve as alternative to mineral fertilizers for improving soil structure and microbial biomass (Suresh et al., 2004, Naeem et al., 2006 and Dauda et al., 2008). Also, failure to use organic fertilizers can deplete soil fertility (Palm et al., 1997). Crops grown with organic fertilizers are not only free from chemical damage rather it is safer and healthier as it is of high nutritional quality and free from contamination from agricultural techniques in addition to providing plant nutrients, improving soil physical properties and microbial properties (Akinfasoye and Akanbi, 2005). Therefore, the usage of organic manures as alternative source of nitrogen would give better result in its growth and yield (Yoldas et al., 2020). Through the scientific facts that we have presented, we have seen that we study the use of organic fertilizers versus chemical one in order to healthy organic production free from both chemicals and contamination, in addition to that the use of organic fertilizers works to reduce production costs and improve agricultural product. Sulphur is essential for physiological and metabolic activities of the plants and in the absence of sufficient sulphur, several essential enzymatic activities and physiological functions are inhibited (Venugopa et al., 2017). Thus, maintenance of an optimum level of sulphur in the soil in relation to other nutrients is essential for the highest garlic yield and best quality. Plants are living in a harsh environment that imposes strikingly manifold stresses on their health and productivity. Biotic stressors (viruses, bacteria, fungi, nematodes, and arthropods, among others) and abiotic stressors (low or high temperature, deficit or excess water, ultraviolet, salt, heavy metals, and so on) which for example, can induce ionic toxicity, osmotic pressure, oxidative damage, and nutrient deficiency (Feng et al., 2014), thereby strongly inhibiting the whole lifecycle of most plants (Guo et al., 2018). However, in the context of climate change and soil salinization, cold/heat, drought and salt usually arise together, posing an increasingly severe threat to plant subsistence and cultivation worldwide (He et al., 2018). Even worse is that biotic stresses may occur simultaneously with them. Hence, strategies must be developed to avoid the adverse effects. Unsaturated fatty acids (UFAs) are coming into the limelight as one of the general defense systems against various biotic and abiotic stresses (Iba, 2002 and He et al., 2018). In higher plants, the most common UFAs are three species: oleic acid, linoleic acid, and linolenic acid (He et al., 2020). Sesame seed contains $50-60 \%$ of high quality oil which is rich in polyunsaturated fatty acids (PUFA) and natural antioxidants, sesamin, sesamolin and tocopherol homologues (Brar and Ahuja, 1979). Hejazi (2010) stated that Suadi sesame oil was noted to contain many unsaturated fatty acids, at a rate of $85.0 \%$. Whilst Egyptian sesame oil was found to contain many unsaturated fatty acids, at a rate of $83.7 \%$ and linoleic acid (45.74) was the largest percentage, followed by oleic acid (39.86\%) and linolenic acid (0.32\%) in Egyptian genotypes (Kurt, 2018). The linoleic acid content was thus found to be higher than the oleic acid content in Egyptian sesame seed oil. Whilst, lower Oleic acid and higher linoleic acid content percentages, in earlier reports, were mentioned by Uzun et al., (2008) than those of Egyptian genotypes. Therefore, Sesame oil is reported to possess anti-oxidant, anti-senescence properties (Ide et al., 2001; Dounis, 2009 and Hejazi, 2010) and also widely consumed as a synergist for insecticides (XU et al., 2005; Doker et al., 2010). According to Bailey (1996) antioxidants are substances that have the ability to delay or inhibit oxidation processes, even when used in small amounts (10-1000 ppm (Borges et al., 1999). Osawa et al. (1985) noted the presence of other types of antioxidants in sesame seeds that work together, namely, sesamol and $\alpha$-tocopherol as well as sesamin and sesamolin, which is more active compared to vitamin $\mathrm{E}$ as an antioxidant (Kamal-Eldin et al., 1994), in the same time Fukuda et al., (1981) and Wanasundara and Shahidi (1998) recorded that Sesamol is a phenolic compound regarded as a major antioxidant component in the sesame oil. Moreover, Sesame oil contains magnesium, calcium, iron, zinc, vitamin B6, and copper (Dounis, 2009). The garlic crop is infested by numerous insect pests at different growth stages which cause considerable rate of losses in yield and the onion thrips (T. tabaci) is one of the main insect pests attacking it during their different stages and caused a great damage, which resulted in the reduction of the crop yield, (Eltez and Karasavuran 2006 and Mahmoud 2008). Thrips tabaci is an extremely polyphagous species and a 
serious pest of a wide range of economically important crops including galic in many parts of the world (Duchovskiene, 2006). It infests all parts of the plant at all growth stages and can lead to 20 to $50 \%$ yield losses thus leads the farmers into the use of pesticides to protect their crops (Bag et al., 2014 and Hala et al., 2015). On the other hand, intensive use of synthetic insecticides to many problems such as pest resistance and resurgence, adverse effects on non-target organisms including humans, natural enemies and negative environmental impacts (Ecobichon, 2001). Thus, use of botanical insecticides as sesame oil is one of plant protection alternatives, generally considered as safe for the environment and health (Pavela, 2007 and Dubey, 2010). Obviously, eco-friendly agriculture has priority for safe products. Therefore, this work aimed to efficacy of poultry manure and sulfur as an organic fertilizer on garlic plants without using any chemicals, and among the objectives also, is the effect of sesame oil on garlic productivity as an antioxidant as well as testing it as the alternative to the chemical insecticide against Thrips tabaci.

\section{Materials and Methods}

The study was carried out during the two successive winter seasons of 2018/2019and 2019/2020at Kaha Experimental Farm (Qalyobia Governorate) of Horticulture Research Institute, Agricultural Research Center, Giza, Egypt to investigate the efficacy of organic fertilizer (OF) including Poultry manure (6 ton/fed) and Sulfur ( $\mathrm{S}_{75}$ and $\mathrm{S}_{150}, 75$ and $150 \mathrm{~kg} / \mathrm{fed}$, respectively) as well as botanical oil (sesame oil at the rate of $5 \mathrm{~cm} / \mathrm{L}$ ) in comparison to the recommended rate of mineral fertilization $\left(\mathrm{N}_{120} \mathrm{P}_{75} \mathrm{~K}_{72} \mathrm{~kg} / \mathrm{fed}, \mathrm{MF}\right)$ and standard commercial insecticide (Marshal 25\%WP) for the control of Thrips tabaci in garlic and its effect on vegetative growth, yield and quality of garlic cultivar Sids 40 . Garlic cloves were obtained from the vegetable research departments of Dokki, Horticulture Research Institute. The sesame oil was obtained from local market of El-Captain Co. for Extracting Natural oils, Herbs and Cosmetics, Cairo, Egypt, i.e. refined oil, for ease of being obtained by vegetable growers later on. Oil was diluted with water and applied as aqueous solution mixed with few drops of liquid soap and molass (as an anti UV light). Poultry manure was collected from private fattening poultry farm at Tokh district, Qaluobia Governorate, Egypt. The manure was dried and sieved to remove feathers and foreign substances. The chemical properties of the poultry manure as well as the physical and chemical soil properties of the experimental field were presented in Table 1. The experiment was carried out in split plot layout as Randomized Complete Blocks Design (RCBD) with three replicates. The plot size was $15 \mathrm{~m}^{2}$ ( $\left.1 / 280 \mathrm{fed}\right)$, i.e., $4.0 \mathrm{~m}$ length $\times 0.75 \mathrm{~m}$ width $\times 5$ ridges (north-south direction). Two weeks before planting, a longitudinal incision was made at the top of the row, and sulfur (S) was added with phosphorus [in case of mineral fertilizer (MF) treatments] or the poultry manure [in case of organic fertilizer (OF) treatments] and mixed with the soil, backfilled, returned to the usual furrow form, and then watered immediately.

Table 1: The chemical properties of the poultry manure and both physical and chemical soil properties of the experimental field during 2018/2019and 2019/2020seasons

\begin{tabular}{|c|c|c|c|c|c|c|c|c|c|c|}
\hline \multicolumn{11}{|c|}{ Poultry manure } \\
\hline Item & $\begin{array}{l}\mathrm{N} \\
(\%)\end{array}$ & $\begin{array}{c}P \\
(\%)\end{array}$ & $\begin{array}{c}K \\
(\%)\end{array}$ & $\begin{array}{c}\text { C/N } \\
\text { Ratio }\end{array}$ & $\begin{array}{l}\text { O.C } \\
(\%)\end{array}$ & $\mathbf{P H}$ & $\begin{array}{c}\text { EC } \\
\text { ds/m }\end{array}$ & $\begin{array}{l}\text { O.M } \\
(\%)\end{array}$ & $\begin{array}{c}\text { ASH } \\
(\%)\end{array}$ & $\begin{array}{c}\text { Moisture } \\
(\%)\end{array}$ \\
\hline 2018/19 & 2.62 & 0.98 & 1.19 & $18.5: 1$ & 38.7 & 8.19 & 3.81 & 65.8 & 32.3 & 24.6 \\
\hline 2019/20 & 2.58 & 0.87 & 1.22 & $21: 01$ & 36.9 & 8.31 & 2.93 & 67.1 & 34.8 & 19.7 \\
\hline \multicolumn{11}{|c|}{ Soil } \\
\hline Item & $\begin{array}{c}\mathrm{N} \\
(\mathbf{p p m})\end{array}$ & $\begin{array}{c}\mathbf{P} \\
(\mathbf{p p m})\end{array}$ & $\begin{array}{c}\mathbf{K} \\
(\mathbf{p p m})\end{array}$ & $\begin{array}{c}\mathbf{C a} \\
(\mathbf{p p m})\end{array}$ & $\begin{array}{c}\text { Mg } \\
\text { (ppm) }\end{array}$ & PH & $\begin{array}{l}\text { Sand } \\
(\%)\end{array}$ & $\begin{array}{l}\text { Silt } \\
(\%)\end{array}$ & $\begin{array}{l}\text { Clay } \\
(\%)\end{array}$ & Texture \\
\hline 2018/19 & 137.59 & 8.95 & 191.02 & 1200 & 271.6 & 8.28 & 19.89 & 18.66 & 61.45 & Clay \\
\hline 2019/20 & 128.99 & 9.73 & 200.35 & 1275 & 281.7 & 8.19 & 21.25 & 19.11 & 62.33 & Loam \\
\hline
\end{tabular}

Cloves of garlic (cv. Sids-40) were sown on first week of October at depth of $5 \mathrm{~cm}$ and spacing of $10 \mathrm{~cm}$. at both seasons. Nitrogen and potassium (in case of MF treatments) were added in three doses 
started after the germination and repeated two times with a month interval. The organic and inorganic fertilizers combined with two sulfur levels treatments were arranged at random in main plots. While the three treatments of foliar sprays [sesame oil (BioC), Marshal 25\% insecticide (ChC) and untreated (UC) control were distributed in the sub plots to obtain 12 treatments (Table 2).

Table 2: Organic and inorganic fertilizers botanical oil and chemical insecticide treatments used in this study

\begin{tabular}{ccccc}
\hline \multirow{2}{*}{ Main plot } & \multicolumn{4}{c}{ Mineral (MF) and organic (OF) fertilizers } \\
\cline { 2 - 5 } & MFS $_{75}$ & \multicolumn{4}{c}{ MFS $_{150}$} & OFS $_{75}$ & OFS $_{150}$ \\
\cline { 2 - 5 } Sub plot & UC & FC & UC & UC \\
& BioC & BioC & BioC & BioC \\
& ChC & ChC & ChC & ChC \\
\hline
\end{tabular}

Foliar spraying with sesame oil extract, insecticide (positive control) and water tap (negative control) began in the early of $3^{\text {rd }}$ week of January four times with 21 days interval. The crop was harvested when the plants attained maturity and showing drying up of most of the leaves and bending over. Care was taken to avoid any kind of bulb injury during lifting. Intercultural operations were done as and whenever required. All other agricultural practices were followed as the recommended of Egyptian Ministry of Agriculture and Land Reclamation, except for keeping the whole area free from any other insecticidal treatments.

\section{Recorded data}

\subsection{Vegetative growth parameters:}

A random sample of five garlic plants was taken from each plot at 120 days after planting for recorded plant height $(\mathrm{cm})$, number of leaves/plant, fresh and dry weight $(\mathrm{g})$, leaf area and total chlorophyll.

\subsection{Yield and its component}

At harvesting date (about 180 days from planting), the samples necessary for yield measurements were taken for recorded the data of bulb weight (g), average clove weight (g), number of cloves/bulb, bulb diameter $(\mathrm{cm})$ and bulb total yield (ton/fed).

\subsection{Chemical constituents:}

Nitrogen, phosphorus and potassium contents were determined according to the methods described by Bremner and Mulvaney (1982), Olsen and Sommers (1982), Jackson (1970), respectively.

\subsection{Measurements of insect control:}

The efficacy of sesame botanical oil combined with organic or inorganic fertilizers for the control of onion thrips in garlic was tested in comparison to the standard commercial insecticide Marshal $25 \%$ WP (carbosulfan) at the recommended rate $(150 \mathrm{~g} / 100 \mathrm{~L}$.) during two production seasons $(2018 / 19$ and 2019/20). The experimental data had been attained, from the plots which received $150 \mathrm{~kg} / \mathrm{fed} \mathrm{sulfur}$ combined with mineral or organic fertilizers treatments, through regular periodical surveys, usually early in the morning. Ten plants per row were randomly selected from the middle row in each plot. Ten leaves were examined per plant using a hand lens. For counting the numbers of Thrips tabaci (immature stages), samples of 30 leaves of the plants were collected at random in the morning for each experimental plot from January to April, during both seasons, examined directly in the field and kept in a tight closed paper bags and transported to laboratory in where all samples were thoroughly examined by stereomicroscope to count the adult as well as both alive and death nymph of T. tabaci and calculate the mean number/plant. Spraying was performed through knapsack sprayer. Efficacy of the tested treatments was evaluated against Thrips tabaci at pre- and post- spray counts at regular intervals of 1 , 3, 7 and 10 days after spraying. The outer plants were never sampled in order to avoid border effects. Evaluation of the treatments efficacy was based on the percentage mortality and product performance 
at each spray and the performance throughout the seasons were determined. Percentage of pest reduction numbers were calculated according to Henderson and Tilton(1955) as following equation:

$$
\text { Reduction } \%=\left(\frac{\mathbf{T a} \times \mathbf{C b}}{\mathbf{T b} \times \mathbf{C a}}-\mathbf{1}\right) \times 100
$$

$\mathrm{T}_{\mathrm{a}, \mathrm{b}}=$ Treatment after and before spray, respectively $\mathrm{C}_{\mathrm{a}, \mathrm{b}}=$ Control after and before spray, respectively

\section{Statistical analysis:}

Data were compared using analysis of variance (ANOVA) procedures according to Gomez and Gomez (1984) through MS STAT programme. The LSD test was used for mean separations of the studied parameters.

\section{Results and Discussion}

Vegetative growth traits (plant height, leaves number/plant, fresh weight/plant, dry weight/plant, total chlorophyll and leaf area), yield and its attributed traits (bulb fresh weight, bulb diameter, number of cloves/bulb, average weight of the clove and total yield/fed) and Bulb constituents (nitrogen, phosphorous and potassium) as affected by organic and inorganic fertilizers are presented in Tables $3 \& 4$.

\section{Vegetative growth traits}

The results shown in Table 3 and Fig. 1 indicated that vegetative growth traits (plant height, leaves number/plant, fresh weight/plant, dry weight/plant and leaf area) were significantly increased gradually as affected by application both mineral and organic fertilizers combined with sulfur rates from 75 until $150 \mathrm{~kg} \mathrm{~S}$ per feddan in both seasons.

Table 3: Vegetative growth traits of garlic as affected by sulfur levels, organic or mineral fertilizer as well as sesame oil foliar spray during 2018/2019and 2019/2020seasons under Thrips tabaci infestation.

\begin{tabular}{|c|c|c|c|c|c|c|c|c|c|c|}
\hline \multirow{2}{*}{ Treatments } & & \multicolumn{5}{|c|}{ Main-plot (Fertilizers) } & \multicolumn{4}{|c|}{ Sub-plot (Insect control) } \\
\hline & & MFS $_{75}$ & MFS $_{150}$ & OFS $_{75}$ & OFS $_{150}$ & LSD & $\mathbf{U C}$ & BioC & ChC & LSD \\
\hline \multirow{2}{*}{ Plant height (cm) } & 2018/19 & 70.32 & 77.14 & 68.11 & 77.51 & 0.50 & 67.75 & 75.23 & 76.83 & 0.46 \\
\hline & $2019 / 20$ & 71.69 & 80.82 & 69.13 & 79.93 & 0.91 & 69.38 & 78.06 & 78.73 & 0.69 \\
\hline \multirow{2}{*}{ No of Leaves/plant } & 2018/19 & 11.09 & 11.65 & 10.69 & 11.47 & 0.21 & 10.34 & 11.50 & 11.84 & 0.19 \\
\hline & $2019 / 20$ & 10.79 & 11.72 & 10.61 & 11.74 & 0.22 & 10.44 & 11.42 & 11.79 & 0.20 \\
\hline \multirow{2}{*}{ Plant Fresh weight (g) } & 2018/19 & 79.39 & 85.93 & 77.89 & 84.66 & 1.32 & 66.58 & 88.85 & 90.48 & 2.68 \\
\hline & $2019 / 20$ & 84.28 & 90.20 & 81.34 & 88.36 & 1.94 & 73.71 & 90.29 & 94.14 & 4.10 \\
\hline \multirow{2}{*}{ Plant Dry weight (g) } & 2018/19 & 9.56 & 11.66 & 9.45 & 11.73 & 0.10 & 9.87 & 10.80 & 11.12 & 0.33 \\
\hline & $2019 / 20$ & 11.49 & 13.75 & 11.24 & 13.52 & 0.24 & 11.34 & 12.89 & 13.26 & 0.38 \\
\hline \multirow{2}{*}{ Total chl. } & 2018/19 & 79.27 & 79.09 & 78.55 & 80.01 & 0.11 & 74.82 & 82.03 & 80.84 & 0.10 \\
\hline & $2019 / 20$ & 78.62 & 78.57 & 76.76 & 79.74 & 0.14 & 72.11 & 82.87 & 80.28 & 0.13 \\
\hline \multirow{2}{*}{$\mathbf{L A}\left(\mathbf{c m}^{3}\right)$} & 2018/19 & 339.62 & 360.21 & 343.11 & 358.02 & 2.38 & 303.40 & 379.09 & 368.22 & 3.61 \\
\hline & $2019 / 20$ & 340.53 & 358.39 & 332.46 & 356.62 & 1.87 & 307.44 & 367.85 & 365.70 & 2.10 \\
\hline
\end{tabular}

$\overline{\mathrm{MF}}=$ mineral fertilizer $\mathrm{OF}=$ Organic fertilizer S: sulfur $\mathrm{BioC}=$ Bio-Control $\quad \mathrm{ChC}=$ Chemical control $. \mathrm{UC}=$ untreated (tap water)

No significant differences between both organic and inorganic fertilizers combined with $150 \mathrm{~kg}$ sulfur in these five traits at both seasons. Applying Organic plus $150 \mathrm{~kg}$ sulfer $\left(\mathrm{OFS}_{150}\right)$ fertilizer increment of plant height, bulb diameter/plant, leaves number/plant, fresh weight/plant, dry weight/plant, total chlorophyll and leaf area by (10.2 \& 11.49\%), (3.4 \& 8.8\%), (6.6 \& 4.8\%), (22.7 \& 17.7\%), $(0.9 \&$ $1.4 \%)$ and $(5.4 \& 4.7 \%)$ over $\mathrm{MFS}_{75}$ (control) treatment in both $1^{\text {st }}$ and $2^{\text {nd }}$ seasons, respectively. The increase due to application of organic fertilizers may be due to the more availability of nutrients, which exerted beneficial effect on vegetative growth of plant. 
Adewale et al., (2011) reported that the result of the poultry manure revealed high content of nitrogen and other nutrients which indicates that high nutrient content is required for a successful growth and yield of garlic. The increase may be due to that organic fertilizers work to gradually supply plants with nutrients, especially microelements such as (Fe, $\mathrm{Zn}$ and $\mathrm{Mn}$ ) and other elements necessary for plant growth. Meanwhile, increased vegetative growth traits progressively with increasing rate of sulphur application was also reported by Alam (1995) and Zaman et al., (2011). On the other hand, Acharya and Kumar (2018) stated that organic manure improves soil texture and help garlic plants to have a good root proliferation, leading to improvement in plant growth as well (Browaldh, 1992) and poultry manure is good source of both macro nutrients $(\mathrm{N}, \mathrm{P}, \mathrm{K}, \mathrm{Ca}, \mathrm{Mg}, \mathrm{S})$ and some micronutrients enhanced growth and yield of garlic plants such as $\mathrm{Zn}, \mathrm{Cu}, \mathrm{Fe}, \mathrm{Mn}$ and $\mathrm{B}$ which helped in the plant metabolic activity through the supply of such important micronutrient in the early vigorous growth that also increase the biological processes within the plant such as the metabolism of organic compounds and enhancing physiological activities and thus improves photosynthesis in plants and can increase soil carbon and N content, soil porosity and enhance soil microbial activity (Ghosh et al., 2004, El-Morsi, 2004 and El-Seifi et al., 2004).
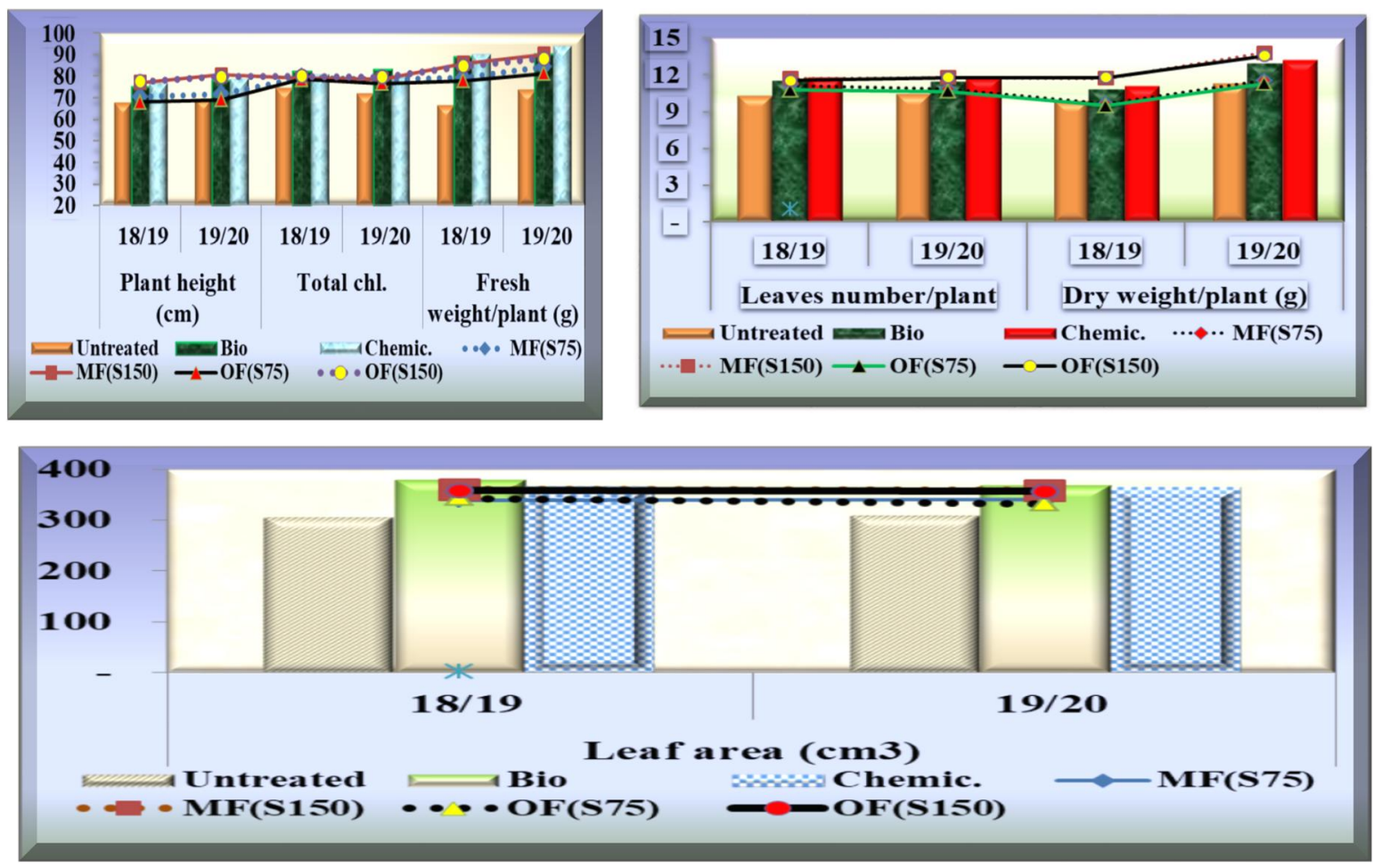

Fig. 1: Vegetative growth traits of garlic as affected by sulfur (S) levels, organic (OF) or mineral fertilizer (MF) as well as sesame oil (Bio) and chemical foliar spray during 2018/2019and 2019/2020 seasons

Significant variations in vegetative growth traits (plant height, leaves number/plant, fresh weight/plant, dry weight/plant, total chlorophyll and leaf area) were observed due to foliar spraying of botanical oil (BioC) or chemical insecticide (ChC) comparing with untreated plants (Table 3$)$. The maximum values of total chlorophyll (82.03 \& 82.87) and leaf area (379.09 \& 367.85) was recorded with sesame oil spraying at $1^{\text {st }}$ and $2^{\text {nd }}$ seasons, respectively. Reverse trend was observed for other vegetative growth traits with no significant differences between sesame oil and carbosulfan (Marshal $25 \%$, WP) foliar spraying. Generally, despite the high infestation of thrips in organic treatments comparing to mineral fertilizer, spraying sesame oil significantly increases or equally to insecticide for all vegetative growth traits except plant height and number of leaves in 1st and both seasons, respectively, this confirms the role of sesame oil as an antioxidant and enhancer for garlic plant more than an effect on the thrips insect. The minimum values of vegetative growth traits were observed in untreated plants. 


\section{Interaction effect:}

Interaction effects between sulfur, organic manures or mineral fertilizer and foliar spray extracts are presented in Table 4 and Figure 2 on vegetative growth traits. As the sulfur level increased from $75 \mathrm{~kg}$ to $150 \mathrm{~kg}$ (under all spraying treatments), $\mathrm{OF} \times$ BioC interaction showed a significant increase in all traits except for chlorophyll, in which the increase was not significant. However, MF $\times$ Bio interaction exhibited a significant increment in plant height, number of leaves and dry weight in both seasons as well as fresh weight in $1^{\text {st }}$ season and a non-significant increase in the remainder traits.

Table 4: Vegetative growth traits of garlic as affected by interactions of sulfur levels, organic or mineral fertilizer as well as sesame oil foliar spray during 2018/2019and 2019/2020seasons under Thrips tabaci infestation.

\begin{tabular}{|c|c|c|c|c|c|c|c|c|c|c|c|c|c|c|}
\hline \multirow{2}{*}{ Treatments } & & \multicolumn{3}{|c|}{$\mathbf{M F S}_{75}$} & \multicolumn{3}{|c|}{ MFS $_{150}$} & \multicolumn{3}{|c|}{$\mathrm{OFS}_{75}$} & \multicolumn{3}{|c|}{ OFS $_{150}$} & \multirow[t]{2}{*}{ LSD } \\
\hline & & UC & BioC & ChC & UC & BioC & ChC & $\mathbf{U C}$ & BioC & ChC & $\mathbf{U C}$ & BioC & $\mathrm{ChC}$ & \\
\hline \multirow{2}{*}{$\begin{array}{c}\text { Plant height } \\
\text { (cm) }\end{array}$} & $2018 / 19$ & 64.77 & 72.79 & 73.39 & 71.36 & 79.20 & 80.86 & 64.17 & 67.53 & 72.64 & 70.70 & 81.40 & 80.43 & 1.69 \\
\hline & $2019 / 20$ & 65.96 & 74.03 & 75.07 & 74.36 & 83.46 & 84.63 & 64.49 & 71.34 & 71.55 & 72.70 & 83.42 & 83.66 & 1.27 \\
\hline \multirow{2}{*}{ Leaves/plant } & $2018 / 19$ & 10.18 & 11.42 & 11.67 & 10.70 & 12.00 & 12.26 & 9.99 & 10.66 & 11.42 & 10.50 & 11.92 & 12.00 & 0.36 \\
\hline & $2019 / 20$ & 9.83 & 11.19 & 11.35 & 10.68 & 12.16 & 12.33 & 10.18 & 10.39 & 11.25 & 11.06 & 11.94 & 12.23 & 0.43 \\
\hline \multirow{2}{*}{ Plant FW (g) } & $2018 / 19$ & 64.26 & 86.28 & 87.62 & 69.55 & 93.39 & 94.84 & 63.63 & 84.36 & 85.69 & 68.87 & 91.36 & 93.75 & 3.5 \\
\hline & $2019 / 20$ & 72.29 & 88.20 & 92.35 & 77.94 & 95.09 & 97.56 & 69.59 & 84.62 & 89.82 & 75.02 & 93.23 & 96.84 & 5.3 \\
\hline \multirow{2}{*}{$\begin{array}{c}\text { Plant DW } \\
\text { (g) }\end{array}$} & $2018 / 19$ & 8.72 & 9.93 & 10.02 & 10.64 & 12.11 & 12.23 & 9.07 & 9.25 & 10.02 & 11.06 & 11.92 & 12.22 & 0.33 \\
\hline & $2019 / 20$ & 10.36 & 11.81 & 12.29 & 12.40 & 14.14 & 14.71 & 10.29 & 11.66 & 11.76 & 12.32 & 13.96 & 14.27 & 1.51 \\
\hline \multirow{2}{*}{ Total chl. } & $2018 / 19$ & 75.64 & 81.64 & 80.54 & 76.10 & 80.13 & 81.03 & 73.55 & 82.43 & 79.66 & 74.00 & 83.90 & 82.13 & 1.792 \\
\hline & $2019 / 20$ & 71.52 & 82.59 & 81.74 & 72.03 & 82.37 & 81.30 & 72.18 & 82.37 & 75.71 & 72.70 & 84.16 & 82.36 & 1.834 \\
\hline \multirow{2}{*}{$\mathbf{L A}\left(\mathrm{cm}^{3}\right)$} & $2018 / 19$ & 294.1 & 360.9 & 363.8 & 309.0 & 389.3 & 382.3 & 301.6 & 368.2 & 359.5 & 308.9 & 397.9 & 367.3 & 8.74 \\
\hline & $2019 / 20$ & 295.4 & 359.9 & 366.2 & 321.0 & 371.1 & 383.0 & 304.2 & 346.1 & 347.2 & 309.1 & 394.3 & 366.4 & 12.6 \\
\hline
\end{tabular}

$\mathbf{M F}=$ mineral fertilizer $\mathbf{O F}=$ Organic fertilizer S: sulfur $\quad$ BioC $=$ Bio-Control $\quad \mathbf{C h C}=$ Chemical control

$\mathrm{UC}=$ untreated (tap water)

Moreover, the highest increment was observed with applying Organic $\left(\mathrm{OFS}_{150}\right)$ fertilizer using sesame oil spray for all vegetative traits except fresh weight $\left(1^{\text {st }}\right.$ season), dry weight $\left(2^{\text {nd }}\right.$ season), chlorophyll (both seasons) in which $\mathrm{OFS}_{150} \times \mathrm{ChC}$ treatment was the highest one. Generally, $\mathrm{OFS}_{150} \times$ BioC interaction produced a significantly increment for plant height $(14.1 \& 12.2 \%)$, number of leaves (11.4\&11.8\%), fresh (31.4 \& 19.6\%), and dry plant weight (12 \& 12.6\%), chlorophyll (10.3 \& 16.8\%) and leaf area $(28.8 \& 22.8 \%)$ in $1^{\text {st }}$ and $2^{\text {nd }}$ seasons, respectively comparing to untreated $\mathrm{MFS}_{150}$ treatment. These trends could be ascribed to the improvement of soil structure which was reflected on water movement by applying organic fertilizers (Abd-ElAti et al., 2016). Increased vegetative growth traits with increasing sulfur fertilization were also reported by Jalil (1998). Furthermore, the improvement of garlic plant growth in response to foliar application of sesame oil extract could be explained based on their beneficial physiological effects, since sesame had some contents of naturally chemical compounds in the seed extract characterized by a high level of unsaturated fatty acids and the presence of antioxidants (Miyahara et al., 2001) as well as phenolic compounds, which is essential for plant physiology due to its contribution for morphological plant form and structure, also, they are involved in plant growth and reproduction process (Cook and Samman 1996). These attributes of sesame oil are due to unsaturated fatty acids (oleic, linoleic and linolenic acids) which are coming into the limelight as one of the general defense systems against various biotic and abiotic stresses (He et al, 2018). 

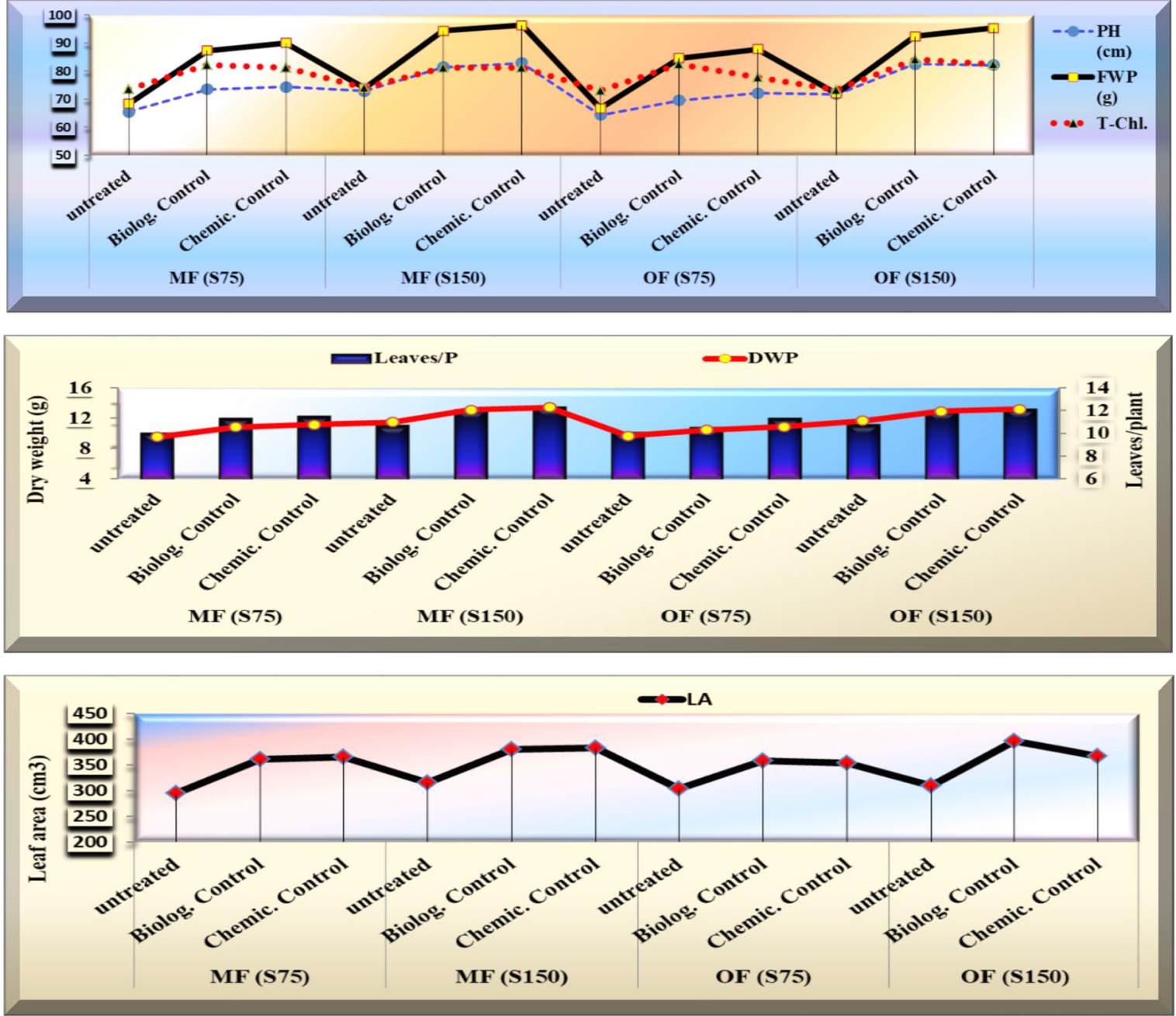

Fig. 2:Vegetative growth traits of garlic as affected by interactions of sulfur (S) levels, organic (OF) or mineral (MF) fertilizer as well as sesame oil (BioC) and chemical (ChC) foliar spray during 2018/2019and 2019/2020seasons

PH: plant height, FW: fresh weight, T-chl: total chlorophyll, DW: dry weight, LA: leaf area

\section{Bulb yield and qualities:}

Data in table 5 and Fig. 3 indicated that bulb fresh weight, bulb diameter, average weight of the clove and total yield/fed had significantly the highest increment in the two study seasons of 2018/2019and 2019/2020with applying $150 \mathrm{~kg}$ sulfur $\left(\mathrm{S}_{150}\right)$ combined with the poultry manure (OF) or mineral fertilizer (MF) over any other treatments with no significant differences between them. On the other hand, bulb fresh weight and total yield in both seasons as well as number of cloves per bulb in $1^{\text {st }}$ one were significantly increased by using poultry manure plus $75 \mathrm{~kg}$ sulfur $\left(\mathrm{OFS}_{75}\right)$ over the control $\left(\mathrm{MFS}_{75}\right)$. Results declared that using Organic plus $150 \mathrm{~kg}$ sulfur $\left(\mathrm{OFS}_{150}\right)$ fertilizer recorded an increment in each of bulb fresh weight, bulb diameter, average weight of the clove and total yield/fed by $(38.9 \& 28.54 \%),(18.54 \& 13.36 \%),(25.04 \& 36.94 \%)$ and $(22.69 \& 23.7 \%)$ over $\mathrm{MFS}_{75}$ (control) treatment in both seasons, respectively. The increase due to application of organic fertilizers may be due to the more availability of nutrients, which contribute in plant growth through its effect on physical, chemical and biological properties of the soil.

These results are in accordance with those obtained by Abdel-Ati (1998), Abou-Hussein et al (2003) and Adewale et al., (2011). They reported that the result of the poultry manure revealed high content of nitrogen and other nutrients which indicates that high nutrient content is required for a successful growth and yield of garlic. 
Table 5: Bulb yield and its attributes of garlic as affected by sulfur levels, organic or mineral fertilizer as well as sesame oil foliar spray during 2018/2019and 2019/2020seasons under Thrips tabaci infestation.

\begin{tabular}{|c|c|c|c|c|c|c|c|c|c|c|}
\hline \multirow{2}{*}{\multicolumn{2}{|c|}{ Treatments }} & \multicolumn{5}{|c|}{ Main-plot (Fertilizers) } & \multicolumn{4}{|c|}{ Sub-plot (Insect control) } \\
\hline & & $\mathbf{M F S}_{75}$ & MFS $_{150}$ & $\mathrm{OFS}_{75}$ & $\mathrm{OFS}_{150}$ & LSD & $\mathbf{U C}$ & BioC & ChC & LSD \\
\hline \multirow{2}{*}{$\begin{array}{l}\text { Bulb Fresh weight } \\
\text { (g) }\end{array}$} & $2018 / 19$ & 51.36 & 64.78 & 60.66 & 71.34 & 0.52 & 53.71 & 66.259 & 66.14 & 1.90 \\
\hline & $2019 / 20$ & 52.03 & 65.75 & 57.95 & 66.88 & 0.55 & 49.80 & 66.79 & 65.37 & 1.35 \\
\hline \multirow{2}{*}{$\begin{array}{c}\text { Bulb } \\
\text { diameter }(\mathrm{cm})\end{array}$} & $2018 / 19$ & 3.51 & 4.27 & 3.42 & 4.16 & 0.14 & 3.54 & 3.99 & 3.99 & 0.12 \\
\hline & $2019 / 20$ & 3.91 & 4.43 & 3.658 & 4.43 & 0.31 & 3.69 & 4.23 & 4.40 & 0.20 \\
\hline \multirow{2}{*}{$\begin{array}{c}\text { Clove weight } \\
(\mathrm{g})\end{array}$} & $2018 / 19$ & 3.01 & 3.97 & 2.86 & 3.77 & 0.23 & 3.18 & 3.53 & 3.49 & 0.06 \\
\hline & $2019 / 20$ & 2.85 & 3.93 & 2.84 & 3.91 & 0.04 & 3.23 & 3.45 & 3.46 & 0.04 \\
\hline \multirow{2}{*}{$\begin{array}{l}\text { Cloves number/ } \\
\text { bulb }\end{array}$} & $2018 / 19$ & 17.89 & 16.77 & 18.42 & 17.48 & 0.54 & 15.54 & 18.73 & 18.65 & 0.54 \\
\hline & $2019 / 20$ & 18.21 & 17.08 & 18.40 & 17.44 & 0.73 & 16.16 & 18.68 & 18.51 & 0.68 \\
\hline \multirow{2}{*}{$\begin{array}{l}\text { Total yield } \\
\text { ( ton/fed) }\end{array}$} & $2018 / 19$ & 7.16 & 8.88 & 7.90 & 8.79 & 0.10 & 6.86 & 8.810 & 8.88 & 0.15 \\
\hline & $2019 / 20$ & 7.18 & 8.94 & 7.72 & 8.88 & 0.04 & 6.99 & 8.78 & 8.75 & 0.02 \\
\hline \multirow{2}{*}{ N \% } & $2018 / 19$ & 1.63 & 1.78 & 1.62 & 1.76 & 0.03 & 1.65 & 1.71 & 1.73 & 0.03 \\
\hline & $2019 / 20$ & 1.62 & 1.78 & 1.61 & 1.76 & 0.03 & 1.65 & 1.71 & 1.72 & 0.03 \\
\hline \multirow{2}{*}{ P \% } & $2018 / 19$ & 0.44 & 0.48 & 0.43 & 0.47 & 0.03 & 0.41 & 0.48 & 0.49 & 0.02 \\
\hline & $2019 / 20$ & 0.45 & 0.51 & 0.41 & 0.49 & 0.03 & 0.41 & 0.49 & 0.50 & 0.02 \\
\hline \multirow{2}{*}{ K\% } & $2018 / 19$ & 1.32 & 1.43 & 1.29 & 1.40 & 0.04 & 1.32 & 1.37 & 1.38 & 0.03 \\
\hline & $2019 / 20$ & 1.33 & 1.41 & 1.31 & 1.39 & 0.03 & 1.34 & 1.38 & 1.37 & 0.02 \\
\hline
\end{tabular}

$\mathrm{MF}=$ mineral fertilizer $\quad \mathrm{OF}=$ Organic fertilizer S: sulfur $\quad \mathrm{BioC}=\mathrm{Bio}-$ Control $\quad \mathrm{ChC}=$ Chemical control $. \mathrm{UC}=$ untreated (tap water)
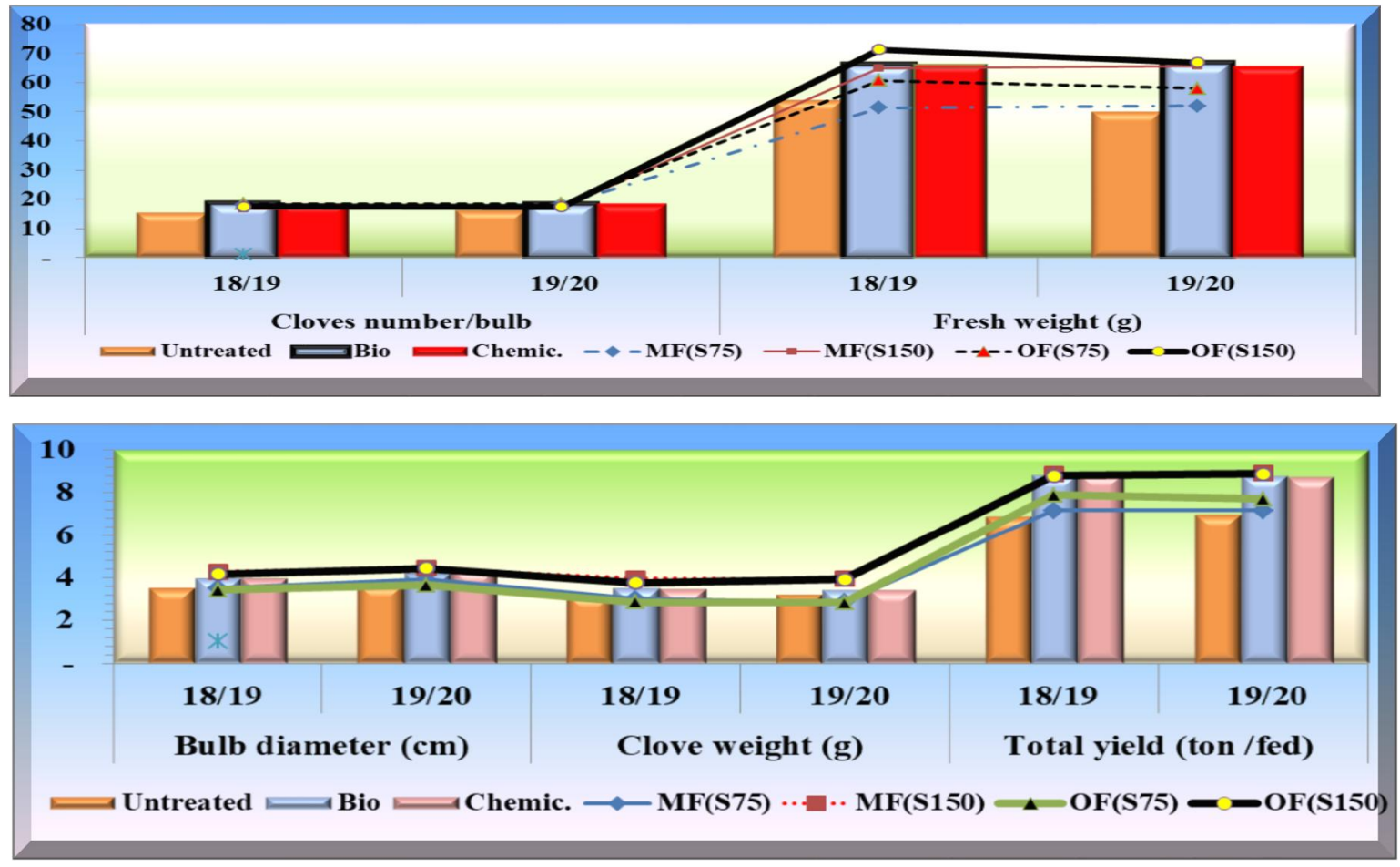

Fig. 3: Both number and fresh weight of cloves/bulb, bulb diameter, average of clove weight and total bulb yield traits of garlic as affected by sulfur (S) levels, organic (OF) or mineral fertilizer (MF) as well as sesame oil (Bio) and chemical foliar spray during 2018/2019and 2019/2020seasons 
Moreover, Mahala et al. (2018) reported that the increased yield and yield parameters with poultry manure might be because of rapid availability and utilization of nitrogen for various internal plant processes for carbohydrates production. Later on these carbohydrates may undergo hydrolysis and get converted into reproductive sugars which ultimately helped in increasing yield. Significant variations in yield and its attributed traits (bulb fresh weight, bulb diameter, average weight of the clove, cloves number and total yield/fed) were observed due to foliar spraying of botanical oil or chemical insecticide (Table 5) comparing with untreated plants. Spraying sesame oil exhibited the highest values of fresh weight ( $66.26 \& 66.79 \mathrm{~g} / \mathrm{bulb})$, Clove weight $(3.53 \& 3.45 \mathrm{~g})$ and cloves number $(18.73 \&$ 18.68 cloves/bulb) in $1^{\text {st }}$ and $2^{\text {nd }}$ season, respectively as well as bulb diameter/plant $(3.99 \mathrm{~cm})$ in $1^{\text {st }}$ season and total yield ( $8.78 \mathrm{ton} / \mathrm{fed})$ in $2^{\text {nd }}$ one. Reverse trend was observed for bulb diameter/plant $(4.40 \mathrm{~cm})$ in $2^{\text {nd }}$ season and total yield $(8.88 \mathrm{ton} / \mathrm{fed})$ in $1^{\text {st }}$ one with no significant differences between sesame oil and carbosulfan (Marshal 24\%, WP) foliar spraying. Generally, despite the high infestation of Thrips tabaci in organic treatments (Table 7) comparing to mineral fertilizer spraying sesame oil, the significantly increases or equally to insecticide for all yield and its attributed traits confirm the role of sesame oil as an antioxidant and enhancer for garlic plant more than an effect on the thrips insect. The minimum values were observed in untreated plants.

\section{Interaction effects}

Interaction effects between sulfur, organic manures or mineral fertilizer and foliar spray extracts are presented in Tables (6) and Figure 4 on yield and its attributed traits. As the sulfur level increased from $75 \mathrm{~kg}$ to $150 \mathrm{~kg}$ (under all spraying treatments), $\mathrm{OF} \times \mathrm{BioC}$ interaction showed a significant increase in all traits except for cloves number/bulb, in which the effect was not significant.

Table 6. Bulb yield and its attributes of garlic as affected by interactions of sulfur levels, organic or mineral fertilizer as well as sesame oil foliar spray during 2018/2019and 2019/2020seasons under Thrips tabaci infestation.

\begin{tabular}{|c|c|c|c|c|c|c|c|c|c|c|c|c|c|c|}
\hline \multirow{2}{*}{\multicolumn{2}{|c|}{ Treatments }} & \multicolumn{3}{|c|}{$\mathbf{M F S}_{75}$} & \multicolumn{3}{|c|}{$\mathbf{M F S}_{150}$} & \multicolumn{3}{|c|}{ OFS $_{75}$} & \multicolumn{3}{|c|}{ OFS $_{150}$} & \multirow{2}{*}{ LSD } \\
\hline & & UC & BioC & ChC & $\mathbf{U C}$ & BioC & ChC & $\mathbf{U C}$ & BioC & ChC & $\mathbf{U C}$ & BioC & ChC & \\
\hline \multirow{2}{*}{$\begin{array}{c}\text { Bulb Fresh weight } \\
\text { (g) }\end{array}$} & $2018 / 19$ & 41.24 & 55.43 & 57.41 & 50.80 & 71.66 & 71.86 & 56.06 & 64.70 & 61.23 & 66.73 & 73.24 & 74.05 & 2.21 \\
\hline & $2019 / 20$ & 40.51 & 56.77 & 58.81 & 51.94 & 71.92 & 73.39 & 52.91 & 65.20 & 55.74 & 53.82 & 73.27 & 73.55 & 2.22 \\
\hline \multirow{2}{*}{$\begin{array}{c}\text { Bulb } \\
\text { diameter }(\mathrm{cm})\end{array}$} & $2018 / 19$ & 3.28 & 3.64 & 3.61 & 3.99 & 4.43 & 4.40 & 3.10 & 3.56 & 3.59 & 3.78 & 4.33 & 4.37 & 0.15 \\
\hline & $2019 / 20$ & 3.36 & 3.09 & 4.29 & 4.04 & 4.58 & 4.66 & 3.34 & 3.704 & 3.93 & 4.02 & 4.55 & 4.73 & 0.23 \\
\hline \multirow{2}{*}{$\begin{array}{c}\text { Clove weight } \\
\text { (g) }\end{array}$} & $2018 / 19$ & 2.90 & 3.08 & 3.05 & 3.82 & 4.06 & 4.02 & 2.60 & 3.01 & 2.98 & 3.42 & 3.96 & 3.92 & 0.16 \\
\hline & $2019 / 20$ & 2.72 & 2.90 & 2.94 & 3.75 & 3.99 & 4.05 & 2.71 & 2.91 & 2.89 & 3.73 & 4.01 & 3.98 & 0.14 \\
\hline \multirow{2}{*}{$\begin{array}{l}\text { Cloves number/ } \\
\text { bulb }\end{array}$} & $2018 / 19$ & 15.86 & 19.20 & 18.60 & 14.70 & 17.80 & 17.80 & 16.98 & 18.98 & 19.31 & 14.63 & 18.92 & 18.89 & 0.89 \\
\hline & $2019 / 20$ & 17.00 & 19.21 & 18.43 & 15.60 & 17.63 & 18.00 & 16.71 & 18.89 & 19.62 & 15.33 & 19.00 & 18.00 & 1.32 \\
\hline \multirow{2}{*}{$\begin{array}{l}\text { Total yield } \\
\text { ( ton/fed) }\end{array}$} & $2018 / 19$ & 6.20 & 7.43 & 7.86 & 7.56 & 9.49 & 9.58 & 6.17 & 8.78 & 8.75 & 7.52 & 9.54 & 9.31 & 0.47 \\
\hline & $2019 / 20$ & 6.22 & 7.67 & 7.64 & 7.81 & 9.42 & 9.58 & 6.18 & 8.52 & 8.45 & 7.75 & 9.53 & 9.35 & 0.29 \\
\hline \multirow{2}{*}{$\mathbf{N} \%$} & $2018 / 19$ & 1.58 & 1.65 & 1.67 & 1.74 & 1.79 & 1.81 & 1.57 & 1.64 & 1.65 & 1.71 & 1.78 & 1.79 & 0.05 \\
\hline & $2019 / 20$ & 1.57 & 1.63 & 1.65 & 1.74 & 1.79 & 1.81 & 1.56 & 1.62 & 1.63 & 1.71 & 1.78 & 1.79 & 0.08 \\
\hline \multirow{2}{*}{ P \% } & $2018 / 19$ & 0.40 & 0.45 & 0.46 & 0.44 & 0.50 & 0.51 & 0.37 & 0.45 & 0.46 & 0.41 & 0.50 & 0.51 & 0.01 \\
\hline & $2019 / 20$ & 0.40 & 0.46 & 0.48 & 0.46 & 0.53 & 0.55 & 0.37 & 0.43 & 0.44 & 0.42 & 0.54 & 0.51 & 0.02 \\
\hline \multirow{2}{*}{ K \% } & $2018 / 19$ & 1.28 & 1.33 & 1.35 & 1.38 & 1.44 & 1.46 & 1.27 & 1.31 & 1.31 & 1.37 & 1.41 & 1.41 & 0.06 \\
\hline & $2019 / 20$ & 1.31 & 1.34 & 1.35 & 1.39 & 1.42 & 1.43 & 1.29 & 1.32 & 1.30 & 1.37 & 1.42 & 1.38 & 0.02 \\
\hline
\end{tabular}

$\mathrm{MF}=$ mineral fertilizer $\quad \mathrm{OF}=$ Organic fertilizer $\mathrm{S}$ : sulfur $\quad \mathrm{BioC}=$ Bio-Control $\quad \mathrm{ChC}=$ Chemical control $. \mathrm{UC}=$ untreated (tap water)

However, $\mathrm{MFS}_{150} \times \mathrm{ChC}$ interaction exhibited a significant increment in bulb yield/fed followed by $\mathrm{OFS}_{150} \times \mathrm{BioC}, \mathrm{MFS}_{150} \times \mathrm{BioC}$ and $\mathrm{OFS}_{150} \times \mathrm{ChC}$, in descending order with no significant differences between them. Noteworthy, no significant differences were spotted among these four interactions in all yield and its attributed traits except cloves number at both seasons. Therefore, applying organic $\left(\mathrm{OFS}_{150}\right)$ fertilizer using sesame oil spraying gave an increase significantly equal to 
the treatment that produced the highest value in all studied yield traits. Generally, $\mathrm{OFS}_{150} \times \mathrm{BioC}$ interaction produced a significantly increment for bulb Fresh weight (44.17 \& 41.07\%), bulb diameter (8.52 \& 12.62\%), average clove weight (3.66 \& 6.93\%), Cloves number $(28.71 \& 21.79 \%)$ and total yield $(26.19 \& 22.02 \%)$ in $1^{\text {st }}$ and $2^{\text {nd }}$ seasons, respectively comparing to untreated $\mathrm{MFS}_{150}$ (The highest mineral fertilization treatment). These trends could be ascribed to the improvement of soil structure which was reflected on water movement by applying organic fertilizers (Batal, 1991, and El-Emam, 1999 and Abd-ElAti et al., 2016). Increased yield and its attributed traits with increasing sulphur fertilization was also reported by Nasiruddin et al. (1993) and Alam (1995).
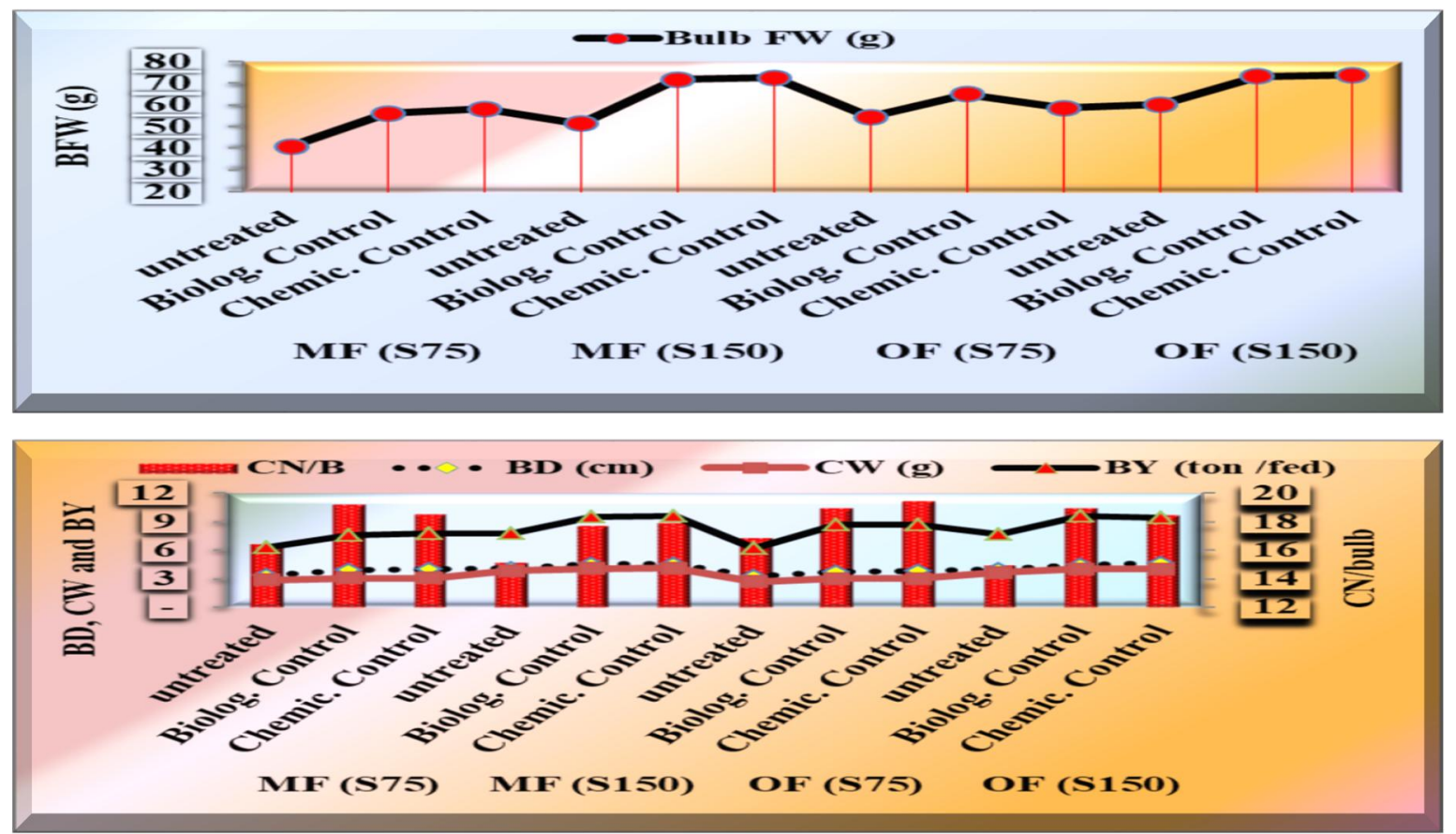

Fig.4: Bulb fresh weight (BFW), number of cloves (CN), bulb diameter (BD), average of clove weight (CW) and total bulb yield (BY) traits of garlic as affected by interaction of sulfur (S) levels, organic (OF) or mineral fertilizer (MF) as well as sesame oil (Bio) and chemical foliar spray during 2018/2019and 2019/2020 seasons

Furthermore, the improvement of garlic plant growth in response to foliar application of sesame oil extract could be explained based on their beneficial physiological effects, since sesame had some contents of naturally chemical compounds in the seed extract characterized by a high level of unsaturated fatty acids and the presence of antioxidants (Miyahara et al., 2001) as well as phenolic compounds, which is essential for plant physiology due to its contribution for morphological plant form and structure, also, they are involved in plant growth and reproduction process (Cook and Samman 1996). These attributes of sesame oil are due to unsaturated fatty acids (oleic, linoleic and linolenic acids) which are coming into the limelight as one of the general defense systems against various biotic and abiotic stresses (He et al, 2018). However, sesame oil extracts are considered an organic farm input as they are environmentally benign and safe for the health of animals and humans. In addition, Osawa et al. (1985) noted the presence of some types of antioxidants in sesame seeds that work together, namely, sesamol and $\alpha$-tocopherol as well as sesamin and sesamolin, which is more active compared to vitamin E as an antioxidant. Fukuda et al., (1981) and Wanasundara and Shahidi (1998) recorded that Sesamol is a phenolic compound regarded as the strongest natural antioxidants component in the sesame oil. In addition, sesame oil extract reported to possess anti-oxidant, anti-senescence properties and considered an indirect additive substances and commonly used as antioxidant (Ide et al., 2001; Dounis, 2009 and Hejazi, 2010) and also widely consumed as a synergist for insecticides (XU et al., 2005 and Doker et al., 2010). The application of bio-stimulants could be considered as a good production strategy for obtaining high yields of nutritionally valuable vegetables with lower impact on the environment. 


\section{Chemical constituents:}

Data in Table 5 and Fig 5, indicated that bulb N, P and K contents in garlic bulb had significantly the highest percentages increment in the two study seasons of 2018/2019and 2019/2020with applying $150 \mathrm{~kg}$ sulfur $\left(\mathrm{S}_{150}\right)$ combined with the poultry manure (OF) or mineral fertilizer (MF) over any other treatments with, On the whole, no significant differences between OF and MF under any sulfur levels for N, P and $\mathrm{K}$ contents in both seasons. Results declared that using Organic plus $150 \mathrm{~kg}$ sulfur $\left(\mathrm{OFS}_{150}\right)$ fertilizer recorded an increment in each of $\mathrm{N}, \mathrm{P}$ and $\mathrm{K}$ contents by (7.98 \& 8.64\%), (6.82 \& 8.89\%) and (6.06 \& 4.51\%) over $\mathrm{MFS}_{75}$ (control) treatment in $1^{\text {st }}$ and $2^{\text {nd }}$ seasons, respectively. These results were in agree with Venugopal et al., (2017) who stated that the integrated role of applied organic manure is more pronounced for availability of sulphur in the soil, may be the released active organic acids during microbial activity that enhanced the oxidation of sulphur (SO) from the native and added sources to sulphate form (SO2-4). However, the increase due to application of organic fertilizers may be due to the more availability of nutrients than most commercial fertilizers (Mousa and Mohamed, 2009 and Oyewole and Oyewole, 2011), which contribute in plant growth through its effect on physical, chemical and biological properties of the soil. Also, Abdel-Ati (1998), Abou-Hussein et al., (2003) and Adewale et al., (2011) reported that poultry manure revealed high content of nitrogen and other nutrients which indicates that high nutrient content is required for a successful growth and yield of garlic. Moreover, Hassaneen (1992) found that sulphur element reduced $\mathrm{pH}$ and conversed the unavailable phosphorus to available form. Also, improves the availability of micro elements (Hetter, 1985) and improves the chemical properties (Kineber et al., 2004).

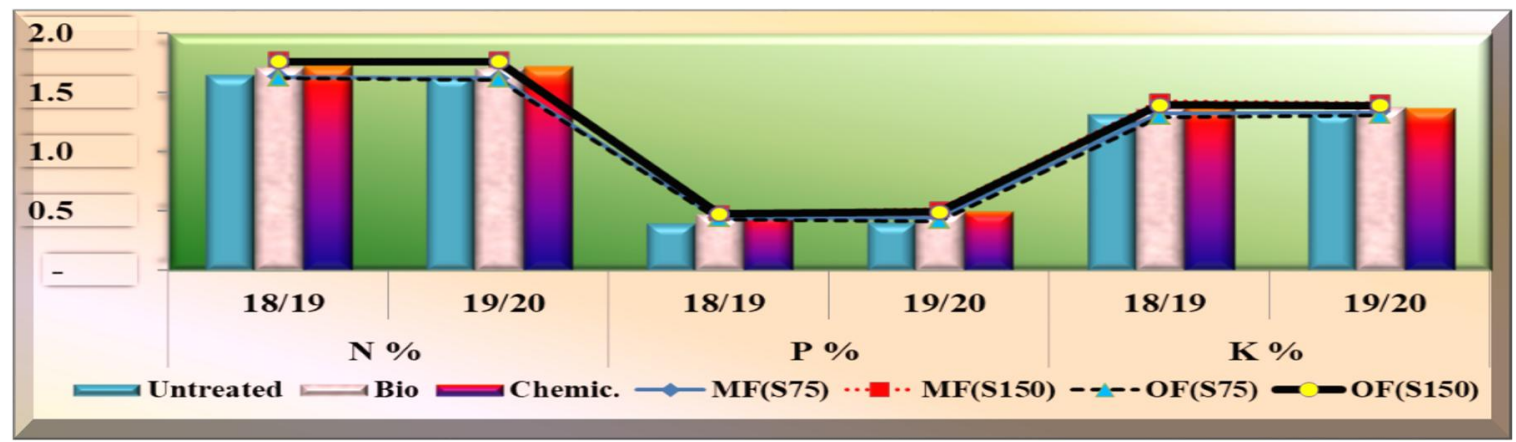

Fig. 5: N, P and K Chemical constituents of bulb garlic as affected by sulfur (S) levels, organic (OF) or mineral fertilizer (MF) as well as sesame oil (Bio) and chemical foliar spray during 2018/2019and 2019/2020seasons

Significant variations in N, P and K contents were observed due to foliar spraying of botanical oil or chemical insecticide (Table 5) comparing with untreated plants. Spraying chemical insecticide and natural sesame oil exhibited the highest values of $\mathrm{N}(1.73 \& 1.71 \%), \mathrm{P}(0.49 \& 0.48 \%)$ and $\mathrm{K}(1.38 \&$ $1.37 \%)$, respectively in $1^{\text {st }}$ season and $\mathrm{N}(1.72 \& 1.71 \%), \mathrm{P}(0.50 \& 0.49 \%)$ and $\mathrm{K}(1.37 \& 1.38 \%)$, respectively in $2^{\text {nd }}$ season with no significant differences between sesame oil and carbosulfan (Marshal $25 \%$, WP) foliar spraying. Generally, despite the high infestation of Thrips tabaci in organic treatments comparing to mineral fertilizer spraying sesame oil (Fig. 9), the significantly increases or equally to insecticide for $\mathrm{N}, \mathrm{P}$, and $\mathrm{K}$ contents confirm the role of sesame oil as an enhancer for garlic plant more than an effect on the thrips insect. The minimum values were observed in untreated plants.

\section{Interaction effects}

Interaction effects between sulfur, organic manures or mineral fertilizer and foliar spray extracts are presented in Table 6 and Fig. 6 on N, P and K contents. As the sulfur level increased from $75 \mathrm{~kg}$ to $150 \mathrm{~kg}$ (under all spraying treatments), $\mathrm{OFS}_{150} \times$ Bio interaction showed a significant increase in all $\mathrm{N}$, $\mathrm{P}$ and $\mathrm{K}$ constituencies with no significant differences between this interaction and any $\mathrm{ChC}$ or BioC combined with $\mathrm{MFS}_{150}$. Therefore, applying organic $\left(\mathrm{OFS}_{150}\right)$ fertilizer using sesame oil spraying gave an increase significantly equal to the treatment that produced the highest percentage of $\mathrm{N}, \mathrm{P}$ and $\mathrm{K}$ in bulb tissue. These trends could be ascribed to the improvement of soil structure which was reflected on water movement by applying organic fertilizers (El-Emam, 1999 and Abd-ElAti et al., 2016). The 
incorrect use of mineral fertilizers may be altered $\mathrm{Ca} / \mathrm{Mg}$ and $\mathrm{Mg} / \mathrm{K}$ ratios, which is detrimental to plants (Loide, 2004) because excess concentrations of one can negatively influence plant growth (Bergmann, 1992) as it decreases yields and also, very important for the uptake of mineral nutrients by plant. On the other hand, Sesame oil contains magnesium, calcium, iron, zinc, vitamin B6, and copper (Dounis, 2009). Therefore, applying manures and sesame oil are very important to maintain the balance of soil cations, for crops that show poor growth due to imbalances, through increasing the concentration of the limiting nutrient so as to raise the base saturation percentages to optimal ranges (Hodges, 2010).

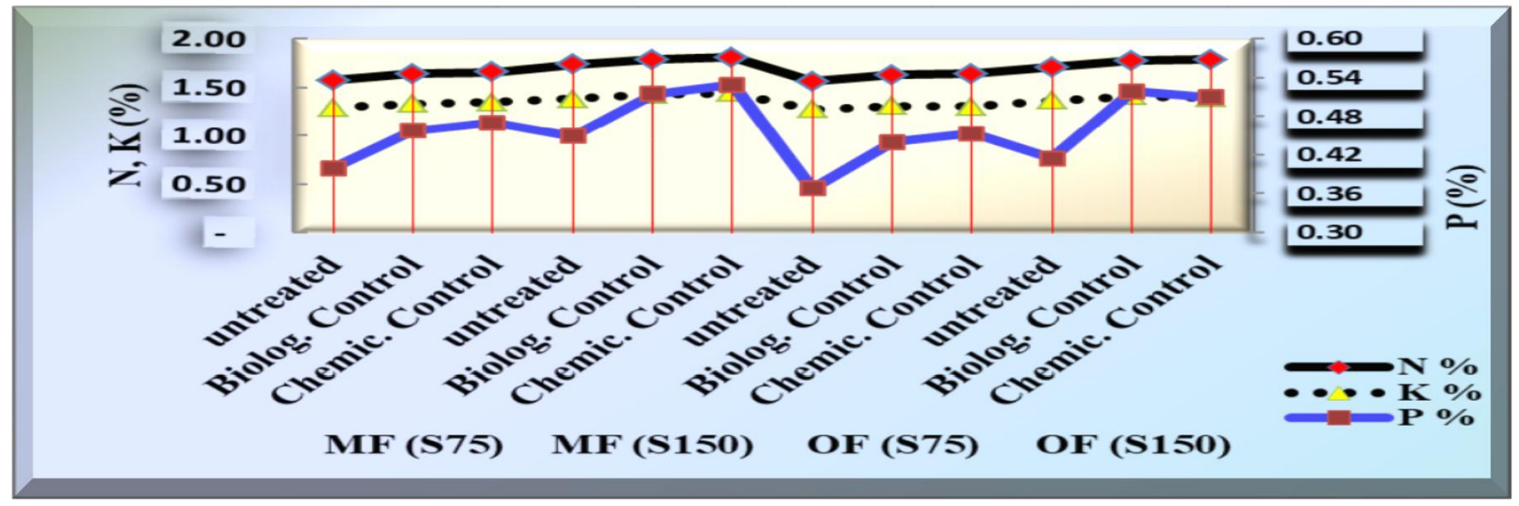

Fig.6: N, P and K Chemical constituents of bulb garlic as affected by interaction of sulfur (S) levels, organic (OF) or mineral fertilizer (MF) as well as sesame oil (Bio) and chemical foliar spray during 2018/2019and 2019/2020seasons

\section{Thrips insects:}

7.1. Seasonal abundance of thrips infesting garlic in relation to organic and inorganic fertilizers:

The results (Table 7 and Fig.7) showed that the population of thrips was observed from the third week of January ( $12^{\text {th }}$ week after planting date) and continued till to $1^{\text {st }}$ week of April $\left(26^{\text {th }}\right.$ week after planting) and reached to a peak level 336 and 462 thrips/plant for mineral and organic fertilizers, respectively during $24^{\text {th }}$ week after planting date, i.e. $4^{\text {th }}$ week of March.
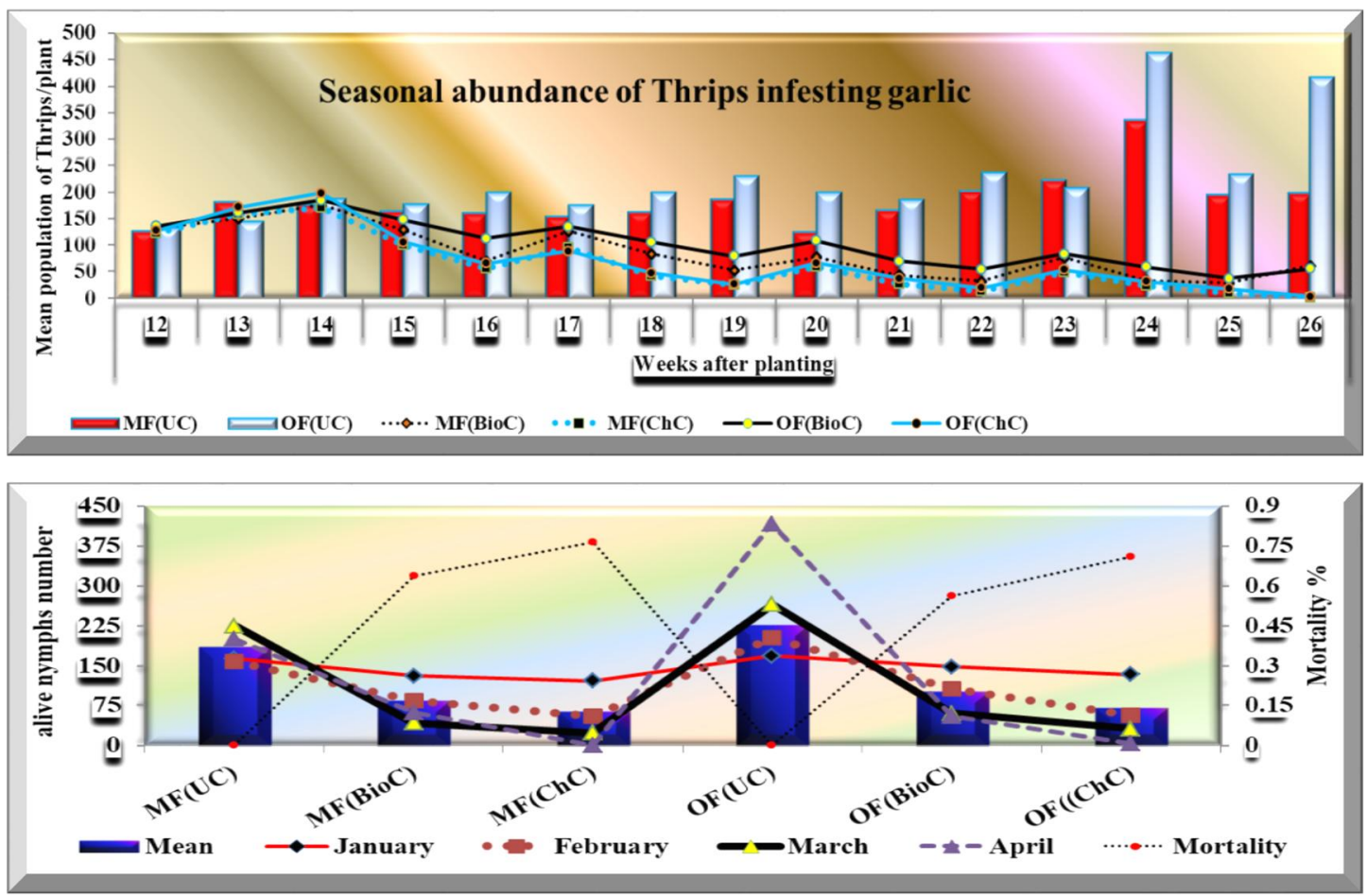

Fig.7: Seasonal abundance of thrips infesting garlic (Upper), number of Thrips per plant pre (UC) and after (BioC\&ChC) spraying as well as mortality percentage (Down) as average both seasons 
Then the thrips population fluctuated between increase and decrease till 200 (mineral fertilization) and 416 (organic fertilization) thrips/plant. In this respect, El-Gendi (1998) noticed the first peak of infestation of thrips on onion in the last week of December with 9.8 nymphs per plant, while second peak occurred in mid-March with 56.5 nymphs per plant. Likewise, Chhatrola et al. (2003) observed the incidence of Thrips tabaci on garlic started at third week of November and continued throughout season. The population gradually increased and reached its first peak during second week of December. Moreover Chhatrola et al. (2006) revealed that the activity of thrips (Thrips tabaci) was comparatively higher on garlic at $6^{\text {th }}, 9-16^{\text {th }}$ and $19^{\text {th }}$ week after sowing. Recently, Nareshchandra (2016) stated that the population of thrips was initiated from $3^{\text {rd }}$ week after planting, i.e. $4^{\text {th }}$ week of January and continued till crop maturity i.e. $4^{\text {th }}$ week of April and reached to a peak level 41.1 thrips/plant during $12^{\text {th }}$ week after planting, i.e. $1^{\text {st }}$ week of April. Thereafter, the thrips population was gradually declined till the time of harvest.

\subsection{The effect of different fertilizers combined with insect control treatments on the mean numbers of thrips:-}

Data in average of both seasons (Table 7) indicated that the gradual reduction of thrips (Thrips tabaci) numbers was observed as a result of six treatment agents; Mineral fertilization plus tap water (MF, UC), Mineral fertilization plus sesame oil as biological control (MF, BioC), Mineral fertilization plus marshal 25\% WP insecticide as chemical control (MF, ChC), Organic fertilization plus sesame oil (OF, BioC), Organic fertilization plus marshal 25\% WP insecticide (OF, ChC) and Organic fertilization plus tap water $(\mathrm{OF}, \mathrm{UC})$. There are highly significant differences between the six treatments.

Table 7: Mean number of T. tabaci alive nymphs/leaf on Garilc plants as average of both 2018/2019and 2019/2020seasons

\begin{tabular}{|c|c|c|c|c|c|c|c|}
\hline \multirow{2}{*}{\multicolumn{2}{|c|}{$\begin{array}{c}\text { Treatments } \\
\text { Sampling date }\end{array}$}} & \multicolumn{3}{|c|}{ MFS $_{150}$} & \multicolumn{3}{|c|}{ OFS $_{150}$} \\
\hline & & $\mathbf{U C}$ & BioC & ChC & $\mathbf{U C}$ & BioC & ChC \\
\hline \multirow{5}{*}{ January } & $1^{\text {st }}$ week & 127 & 131 & 122 & 133 & 135 & 127 \\
\hline & $2^{\text {nd }}$ week & 183 & 150 & 158 & 145 & 161 & 171 \\
\hline & $3^{\text {rd }}$ week & 177 & 175 & 169 & 187 & 184 & 198 \\
\hline & $4^{\text {th }}$ week & 165 & 128 & 99 & 177 & 147 & 105 \\
\hline & $5^{\text {th }}$ week & 161 & 69 & 56 & 199 & 112 & 65 \\
\hline \multirow{4}{*}{ February } & $1^{\text {st }}$ week & 154 & 126 & 95 & 175 & 134 & 88 \\
\hline & $2^{\text {nd }}$ week & 164 & 83 & 41 & 200 & 105 & 47 \\
\hline & $3^{\text {rd }}$ week & 187 & 52 & 25 & 230 & 79 & 26 \\
\hline & $4^{\text {th }}$ week & 126 & 77 & 59 & 199 & 108 & 66 \\
\hline \multirow{5}{*}{ March } & $1^{\text {st }}$ week & 167 & 43 & 26 & 185 & 69 & 37 \\
\hline & $2^{\text {nd }}$ week & 203 & 32 & 12 & 237 & 54 & 19 \\
\hline & $3^{\text {rd }}$ week & 223 & 76 & 49 & 207 & 83 & 53 \\
\hline & $4^{\text {th }}$ week & 336 & 33 & 23 & 462 & 58 & 31 \\
\hline & $5^{\text {th }}$ week & 195 & 28 & 10 & 234 & 37 & 17 \\
\hline April & $1^{\text {st }}$ week & 200 & 61 & 0 & 416 & 55 & 3 \\
\hline \multicolumn{2}{|c|}{ Total } & 2769 & 1265 & 943 & 3385 & 1521 & 1053 \\
\hline \multicolumn{2}{|c|}{ Mean } & $185^{b}$ & $84^{\mathrm{c}}$ & $63^{d}$ & $226^{\mathrm{a}}$ & $101^{\mathrm{c}}$ & $70^{\mathrm{c}}$ \\
\hline \multicolumn{2}{|c|}{ \% Mortality } & -- & $63.68 \% \mathrm{ab}$ & $76.12 \% \mathrm{o}^{\mathrm{a}}$ & -- & $56.25 \% \mathrm{~b}$ & $70.94 \%{ }^{\mathrm{a}}$ \\
\hline
\end{tabular}

$\mathrm{MF}=$ mineral fertilizer $\quad \mathrm{OF}=$ Organic fertilizer $\mathrm{S}$ : sulfur $\quad \mathrm{BioC}=\mathrm{Bio}-\mathrm{Control} \quad \mathrm{ChC}=\mathrm{Chemical}$ control $. \mathrm{UC}=$ untreated (tap water) $\mathrm{F}$ value between treatments $=17.00 * * *($ L.S.D. $=34.13) \quad$ F valuefor Mortality $\%=11.23 * *$ (L.S.D.=16.03)

It is clear that the six treatments can be arranged in descending orders groups as follows: first group (Organic fertilization without control (OF, UC) was explained highly infestation with mean numbers 226/individuals. The second group contained Mineral fertilization without control (MF, UC) with means 185/individuals. The third, fourth and fifth groups are Organic fertilization plus sesame oil (OF, BioC); Mineral fertilization plus sesame oil (MF, BioC) and Organic fertilization plus marshal insecticide $(\mathrm{OF}, \mathrm{ChC})$ which exhibited the moderate effect with means infestation of 101, 84 and 70 individuals, respectively with no significant differences between them. Finally, the sixth group: Mineral fertilization plus marshal insecticide (MF, ChC) showing low infestation with means 70 and 63/individuals, respectively. Moreover, the mortality percentage (Fig. 7) of Thrips tabaci as affected by the fertilizers and foliar spraying by sesame oil extract or marshal insecticide cleared that the studied 
treatments can be arranged in descending orders as MFChC $>$ OFChC $>$ MFBioC $>$ OFBioC with means mortality of 76.12, 70.94, 63.68 and $56.25 \%$, respectively. However, no significant differences were observed between MFChC, OFChC and MFBioC. These results agree with the previous discussion of yield and its attributed traits as affected by the role of sesame oil as an antioxidant and enhancer for garlic plant more than an effect on the thrips insect, despite the high infestation of Thrips tabaci in organic treatments comparing to mineral fertilizer spraying sesame oil.

\subsection{Efficiency of some compound against Thrips tabaci:}

Mean reduction percentages in population of $T$. tabaci nymph after spray applications of both sesame oil extract as biological control and the chemical insecticide (marshal 25\% WP), for 4 times combined with both organic and mineral fertilizer treatments are shown in Table 8 and Fig. 8.

Table 8: Mean reduction (number and percentage) of $T$. tabaci on Garlic plant as average of 2018/2019and 2019/2020seasons

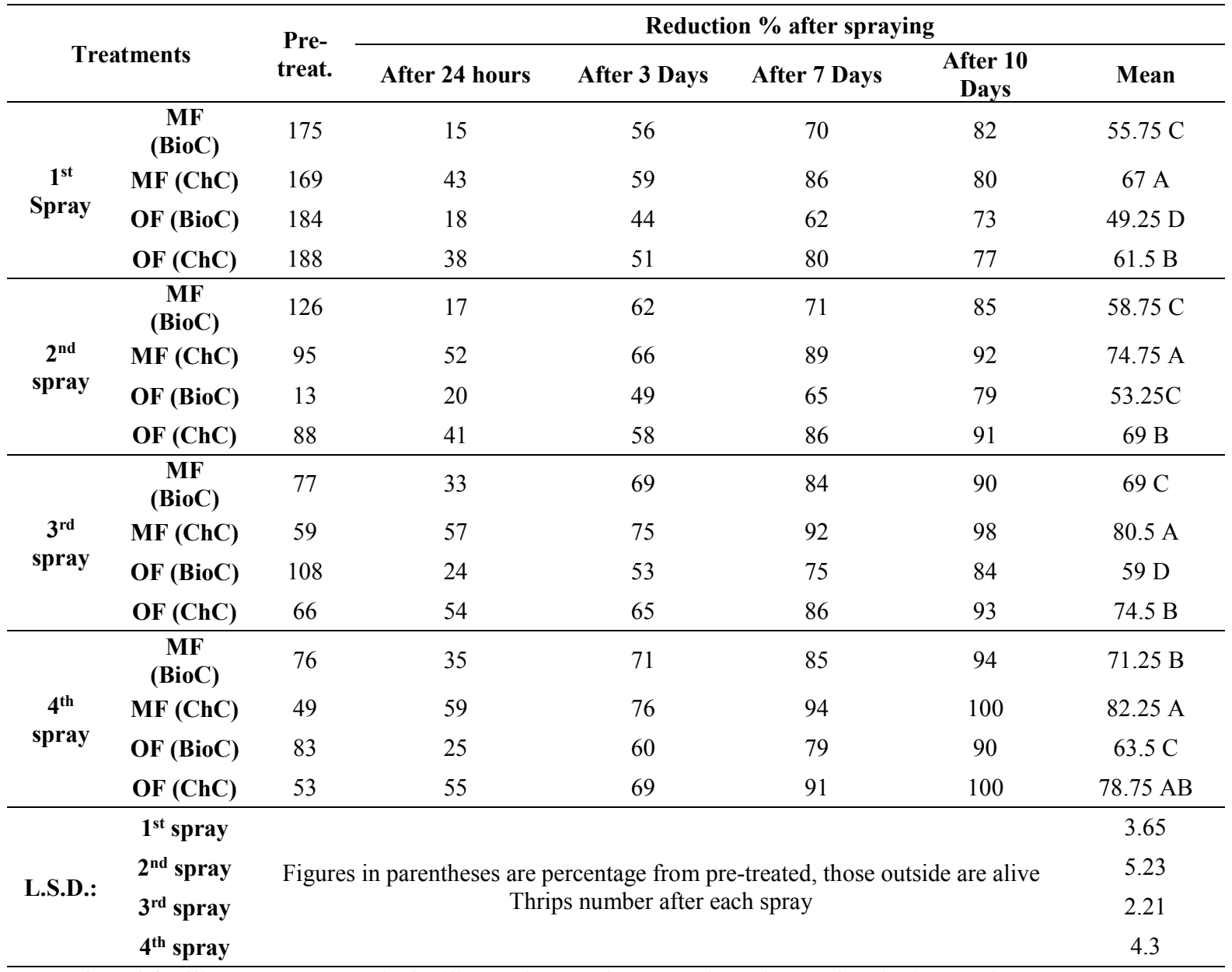

$\mathrm{MF}=$ mineral fertilizer $\mathrm{OF}=$ Organic fertilizer $\mathrm{BioC}=\mathrm{Bio}-$ Control $\quad \mathrm{ChC}=$ Chemical control .

The data recorded at one day after first spraying indicated that the four control agents can be arranged in descending orders as follows: Mineral fertilization plus chemical control, Organic fertilization plus chemical control, Mineral fertilization plus biological control and Organic fertilization plus biological control with means reduction of $67,61.5,55.75$ and $49.25 \%$ for the four agents, respectively. According to the mean, percentage of reduction in $T$. tabaci counts after treatment, the treatments can be significantly divided into four groups (F value 4.24*, L.S.D. $=3.65$ ). 


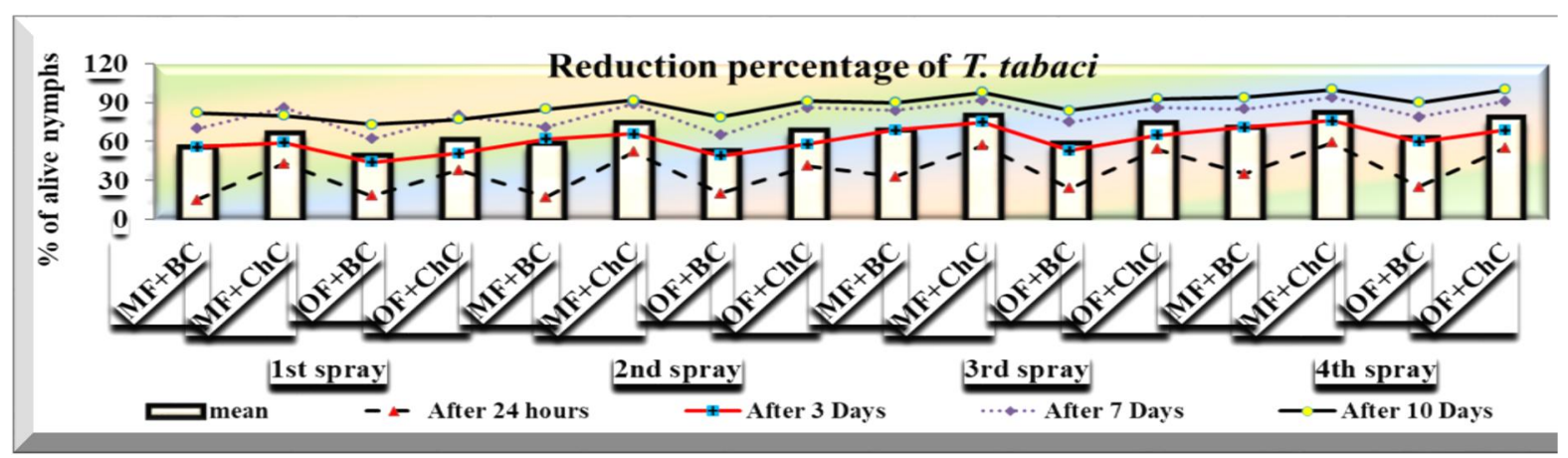

Fig. 8: Reduction percentage of Thrips tabaci as affected by sesame oil (BC) and marshal insecticide (ChC) spray application.

Likewise, reduction percentage after the $2^{\text {nd }}$ spray indicted that the four control agents can be arranged in same of the $1^{\text {st }}$ spray descending orders, i.e., mineral fertilization plus chemical control, organic fertilization plus chemical control, mineral fertilization plus biological control and organic fertilization plus biological control with means reduction of $74.75,69,58.75$ and $53.25 \%$ in $2^{\text {nd }}$ spray; $80.5,74.5,69$ and $59 \%$ in $3^{\text {rd }}$ spray as well as $82.25,78.75,71.25$ and $63.5 \%$ in $4^{\text {th }}$ spray for the four agents, respectively (Table 8). According to the significance differences of the reduction percentage after the four spray times among the studied treatments, it can be significantly divided into the four above mentioned groups. As for the number of reduction and remaining alive thrips/plant after each spray, data in the Table 8 and Fig. 9 recorded at ten days after third and fourth spraying indicated that all the treatments recorded significant lower number of thrips per plant as compared to control. However, MFChC and $\mathrm{OFChC}$ treatments $\left(98\right.$ and $93 \%$ reduction after $3^{\text {rd }}$ spray and $100 \%$ reduction for both treatments after the $4^{\text {th }}$ spray) were found to be the most effective treatment as compared to other treatments followed by MFBioC (90 and 93\% reduction) and OFBioC ( 84 and 90\% reduction) after $3^{\text {rd }}$ and $4^{\text {th }}$ spray, in descending order. Therefore, the highest number of thrips decreased after third and fourth sprayings was using OFBC treatment by 84 and $90 \%$ reduction. Although, the organic and mineral fertilizers treated by chemical insecticide did not leave any insects on the plant $(100 \%$ reduction), the total yield (average of the two seasons) of the organic treatment interacted with sesame oil (OFBioC) was 9.535 ton/fed significantly equal to yield of MFChC (mineral plus chemical insecticide, 9.580 ton/fed) and $\mathrm{OFChC}$ (organic plus chemical insecticide, 9.580 ton/fed). It was also noticed that this treatment (OFBioC) significantly exceeded the bulb fresh weight and the number of cloves per plant, while it was significantly equal with both diameter and weight of garlic clove compared to the treatment of mineral fertilization plus the chemical insecticide. It is believed that this is due to the effect of the sesame oil (in manure treatment) as a catalyst and enhancer for the garlic plant in resisting the presence of the insect and reducing the harm or, on the other hand inhibiting the insect activity in causing any harm (rather than being an insecticide) confirming the role of sesame oil as an enhancer and/or antioxidant for garlic plant more than an effect on the thrips insect as previous in our discussion. In this respect, Singh et al. (2014) reported that all the biopesticides increase the yield and shelf life of garlic by three weeks in comparison to control and dimethoate $(0.03 \%)$ treated plots. In addition, sesame oil extract reported to possess anti-oxidant, anti-senescence properties and considered an indirect additive substances and commonly used as antioxidant (Dounis, 2009 and Hejazi, 2010) and also widely consumed as a synergist for insecticides (XU et al., 2005; Doker et al., 2 010). Thus, the application of bio-stimulants could be considered as a good production strategy for obtaining high yields of nutritionally valuable vegetables with lower impact on the environment.

\section{Conclusion}

The results of our studies highlighted the overall positive effects of organic fertilization, botanical oil (minimum sesame oil percentage) on bulb qualities for healthy human use and as an organic seeds, with general increases compared to inorganic fertilization. However, organic fertilizers (without spraying sesame oil) had no significant effect on crop yields compared to conventional systems while, they had a significant effect on bulb quality and botanical healthy. However, the response of crop yield to these practices was related to specific soil conditions of the area as well as the composition, 
type and quantity of organic fertilizer, abundance of sulfur and foliar spray by sesame oil, in the same time, with potential negative effects in areas with low phosphorous and potash. Thus, to avoid potential problems with nutritional deficits for crops and water stress, the growth of crops by minimum concentration of sesame oil spray together with increases in soil organic matter and sulphur content that positively improve insects resistance, soil quality and make the agro-ecosystem more resilient to drought and erosion events, with no negative effects on crop yield. The incorporation of such systems and practices in agricultural policy measures could provide a meaningful contribution to securing the long-term soil quality and ensuring healthier human nutrition. Our results also suggested the bulb quality as an organic seeds were the main drivers of long-term our study

\section{References}

Abdel-Ati Y. Y. (1998). Yield and quality of potato as affected by phosphorus, chicken manure and seed tuber size. Assiut J. Agric. Sci., 29 (5), 129-147.

Abd-ElAti Y. Y., Y. T. Abd Al-Mageed, N. S. Youssef, Y. M. M. Moustafa and M. Y. Shereen ,2016. Response of garlic (Allium sativum L.cv.Egaseed1) to organic fertilization and phosphorus levels. Minia J. of Agric. Res. \& Develop., 33(4): 613-634.

Abou-Hussein, S.D., A. F. Abou-Hadid and T. El-Shorbagy, 2003. Effect of cattle and chicken manure with or without mineral fertilizers on vegetative growth, chemical composition and yield of potato crops. Acta Hortic. 608, 73-79.

Acharya S. and H. Kumar, 2018. Effect of some organic manure on growth and yield of garlic in greenhouse condition at cold desert high altitude ladakh region. defence life sci. j., 3 (2): 100-104.

Adewale O. M, O. S. Adebayo and T. A. Fariyike, 2011. Effect of poultry manure on garlic (Allium sativum L) production in Ibadan, South Western Nigeria. Continental j. Agr. Sci. 5 (2): 7-11.

Adhikari, P., B. R. Baral and J. Shrestha, 2016. Maize response to time of nitrogen application and planting seasons. Journal of Maize Research and Development, 2(1), 83-93.

Akinfasoye, J. A and W. B. Akanbi, 2005. Effect of organic fertilizer and spacing on growth and yield of celosia (Celosia argentea L.) Proc.23rd HORTSON conference, Port Harcourt, 18-22nd September.

Alam, M. D., 1995. Effect of Paclobutrozol and S fertilizer on the growth yield and sulphur content of garlic. M .S Thesis, Bangladesh Agril. Univ., Mymensingh. pp. 92-95.

Bag, S., S. I. Rondon, K. L. Druffel, D. G. Riley, and H. R. Pappu (2014). Seasonal dynamics of thrips (Thrips tabaci) (Thysanoptera: Thripidae) transmitters of Iris yellow spot virus: a serious viral pathogen of onion bulb and seed crops. J. Econ. Entomol., 107: 75-82

Bailey, A. E., 1996. Bailey's Industrial Oil and Fat Products. 5th Ed., v. 3, John Wiley: New York

Batal, K. M., 1991. Effects of nitrogen source, rate, and application frequency on yield and quality of onion. Hort Science 26: 454-608.

Bergmann, W., 1992. Nutritional Disorders of Plants. Development, Visual and Analytical Diagnosis; Gustav Fisher Verlag: Jena, Germany.

Borges, M. F. M., F. A. M. Silva and M. A. Ferreira, 1999. Métodos para avaliação do grau de oxidação lipídica e da capacidade antioxidante. Química Nova, 22, n. 1, 94 (In Portuguese).

Brar G, and K. L. Ahuja, 1979. Sesame: its culture, genetics, breeding and biochemistry. Annu Rev Plant Sci.;1:245-313.

Bremner, J.M and C. S. Mulvaney, 1982.Total nitrogen. In: Page, A.L.R.H. Miller and D.R. Keeney (Ed.)", Methods of Soil Analysis, Madison, W.I. U.S.A., pp.:595 - 624.

Browaldh, M., 1992. Influence of organic and inorganic fertilizer on common bean (Phaseolus valagnis L.) grown in p-fixing Malic Andosol. Biol. Agric. Hort., 1992, 9(8), 45-56. doi: 10.1080/01448765.1992.9754619.

Chhatrola, D. P., H. J. Vyas and K. P. Baraiya, 2003. Influence of abiotic factors on population buildup of thrips, Thrips tabaci in garlic. Indian J. Plant Prot. 31 (2): 98-100.

Chhatrola, D. P., H. J. Vyas and K. P. Baraiya, 2006. The effects of irrigation, sowing date, and nitrogen on the incidence of garlic thrips (T. tabaci) on garlic. Indian J. Ent., 68(2): 121-124.

Cook N. C. and S. Samman, 1996. Flavonoids - Chemistry, metabolism, cardioprotective effects and dietary sources. J. Nutrit. Bioch., 7: 66-76 
Dauda, S. N., F. A. Ajayi and E. Ndor, 2008. Growth and yield of water melon (Citrullus lanatus) as affected by poultry manure application. - Journal of Agriculture and Social Science 4: 121-124.

Diriba-Shiferaw G., R. Nigussie-Dechassa, K. Woldetsadik, T. Getachew and J. J. Sharma, 2013. Growth and Nutrients Content and Uptake of Garlic (Allium sativum L.) as Influenced by Different Types of Fertilizers and Soils. Sci. Technol. \& Arts Res. J., 2(3): 35-50.

Doker, O., U. Salgin, N. Yieldiz, M. Aydognus and A. Calimi, 2010. Extraction of sesame seed oil using supercritical CO2 and mathematical modeling. Journal of Food Engineering, 97, n. 3, 360

Dounis S., 2009. Nuts and Seeds Provide Health Benefits. USA: HealthyNutrition.me; [cited 8 July 2009]; Available from: http://healthynutrition.me/?p=977.

Dubey N. K., R. Shukla, A. Kumar, P. Singh and B. Prakash, 2010. Global scenario on the application of natural products in integrated pest management programmes. In: Dubey, N. K. (ed.) Natural products in plant pest management. CAB International, UK, pp. 120.

Duchovskiene, L., 2006. The Abundance and Population Dynamics of Onion Thrips (Thrips tabaci Lind.) in Leek under Field Conditions. Agro. Res., 4: 163-166.

Ecobichon, D. J., 2001. Pesticide use in developing countries. Toxicology, 160, pp. 27-33.

El- Seifi, S.K; Sowsan M.H. Sarg; A.I.Abd El- Fattah and M.A. Mohamed, 2004. Effect of biofertilizers and nitrogen levels on the productivity and quality of Chinese garlic under sandy soil conditions. Zagazig Journal of Agriculture Research, 31 (3): 889- 914.

El-Emam, M.A.A.E., 1999. Studies on nutrients availability from plant residues and different organic fertilizers. M. Sc. Thesis, Zagazig Univ., (Benha Branch) Egypt.

El-Gendi, S. M., 1998. Population fluctuation of Thrips tabaci Lind. on onion plant under fayoun environmental conditions. Arab Universities Journal of Agricultural Sciences, 6(1): 267-276.

El-Morsy, A.H.A., 2004. Effect of some potassium levels and mepiquat choloride (PIX) on growth, yield and its quality of garlic (Allium sativum L.) Journal of Agriculture Science, Mansoura University, 29 (7): 4149- 4158.

Eltez, S. and Y. Karasavuran, 2006. Studies in the determination of population fluctuation of Thrips tabaci Lindeman (Thysanoptera: Thripidae) in processing tomato production areas in Izmir province, Turkey. Ege-Univ., Ziraat-Fakltesi-Dergisi, ;43 [3]:31-42.

El-Zohiri, S. S. M., 2003. Physiological studies on garlic crop. Ph.D. Thesis Zagazig University, Benha Branch, Faculty Agriculture, Moshtohor, pp160.

Feng, Z. T., Y. Q. Deng, , H. Fan, Q. J. Sun, N. Sui and B. S. Wang, 2014. Effects of $\mathrm{NaCl}$ stress on the growth and photosynthetic characteristics of Ulmus pumila L. seedlings in sand culture. Photosynthetica 52, 313-320.

Fukuda Y, T. Osawa and M. Namiki, 1981. Antioxidants in sesame seed. Nippon Shokuhin Kogyo Gakkaishi 28, 461-464.

Ghosh, P. K., P. Ramesh, K. K. Bandyopadhyay, A. K. Tripathi, K. M. Hati, A. K. Misra and C. L. Acharya, 2004. Comparative effectiveness of cattle manure, poultry manure, phosphocompost and fertilizer-NpK on three cropping systems in vertisols of semi-arid tropics. I. Crop yields and system performance. Bioresource Technol., 95: 77-83. doi:10.1016/j.biortech.2004.02.011.

Gomez, K. A. and A. A. Gomez, 1984. Statistical Procedures for Agricultural Research. 2 nd ed., John Wiely and Sons, New York.

Guo, J. R., Y. D. Li, G. L. Han, J. Song and B. S. Wang, 2018. NaCl markedly improved the reproductive capacity of the euhalophyte Suaeda salsa. Funct. Plant Biol. 45, 350-361. doi: $10.1071 / \mathrm{fp} 17181$

Hala, H. Alakhder, Zeinab E. Ghareeb and E. M. Rabie, 2015. Evaluation Some Genotypes of Soybeans Yield Under Pest Infestation. International Journal of Scientific Research in Agricultural Sciences, 2 (Proceedings), pp. 007-017, Available online at http://www.ijsrpub.com/ijsras. Conference organizer retains the copyright of this article 7.

Hassaneen, M. N. A., 1992. Effect of sulphur application to calcareous soil on growth and certain metabolic changes in some crops. J. Agric. Sci. Mansoura Univ., 17(10): 3184-3195.

He M., C. Q. He and N. Z. Ding, 2018. Abiotic Stresses: General Defenses of Land Plants and Chances for Engineering Multistress Tolerance. Front. Plant Sci. 9:1771. doi: 10.3389/fpls.2018.01771

He, M., C. X. Qin, X. Wang and N. Z. Ding, 2020. Plant unsaturated fatty acids: Biosynthesis and regulation. Front. Plant Sci. 11, 390. doi: 10.3389/fpls.2020.00390 
Hejazi, Maha Ahmad, 2010. Evaluation of physical, chemical and biological properties of seeds oil in Kingdom of Saudia Arabia. Ph.D. Thesis., College of Art and Design, KING Abdulaziz University, 153 pp., in Arabic

Henderson, C. F. and E. W. Tilton, 1955. Test with acaricides against the brown wheat mite. J. Econ. Ent.; 48: 157-161.

Hetter, B., 1985. Utilization of sulphur for amendment on calcareous soil in Jordan. Proceedings of the $2^{\text {nd }}$ Arab Regional Conference on Sulphur and its Usages. Ryiadh, Saudi Arabia, 1: 85-100.

Hodges, S. C., 2010. Soil Fertility Basics; Soil Science Extension, North Carolina State University: Raleigh, NC, USA, pp. 1-75.

Iba K., 2002. Acclimative response to temperature stress in higher plants: approaches of gene engineering for temperature tolerance. Ann Rev Plant Biol., 53:225-245

Ide T., L. Ashakumary, Y. Takahashi, M. Kushiro, N. Fukuda and M. Sugano, 2001. Sesamin, a sesame lignan, decreases fatty acid synthesis in rat liver accompanying the down-regulation of sterol regulatory element binding protein-1. Bioch. et Biophys. Acta (BBA) - Molecular and Cell Biology of Lipids, 1534 (1): 1-13.

Jackson, M. L., 1970. Soil chemical analysis.Prentic Hall, Englewood Ceiffs, N.J.

Kamal-Eldin A, L. A. Appelqvist and G. Yousif, 1994. Lignan analysis in seed oils from four sesame species: comparison of different chromatographic methods. J. Am. Oil Chem. Soc. 71, 141-147.

Kineber, M. F. A., A. A. El-Masry and M. N. Gohar, 2004. Effect of sulphur application and nitrogen fertilization on yield and its quality for some flax varieties in alkaline soil. Ann. Agric. Sci., 49(1): 53-69

Kurt C., 2018. Variation in oil content and fatty acid composition of sesame accessions from different origins. Grasas Y Aceites 69 (1):; e241 ISSN-L: 0017-3495.

Loide, V., 2004. About the effect of the contents and ratios of soil's available calcium, potassium and magnesium in liming of acid soils. Agron. Res., 2: 71-82.

Macintyre-Allen J. K., C. D. Scott-Dupree, J. H. Tolman, and C. R. Harris, 2005. Evaluation of Sampling Methodology for Determining the Population Dynamics of Onion Thrips (Thysanoptera: Thripidae) in Ontario Onion Fields. J. Econ. Entomol., 98:2272-2281.

Mahala, P., M. R. Chaudhary and O. P. Garhwal, 2018. Yield and quality of rabi onion (Allium cepa L.) influenced by integrated nutrient management.Int. J. Curr. Microbiol. App. Sci. 7(5): 33133321

Mahmoud, H. H., 2008. Ecological Studies on certain insect pests of onion withspecial emphasis on the onion bulb fly Eumerus anoenus Loew. Ph.D. Thesis, Thesis, Fac., Agric.,Cairo Unvi, Egypt.

Miyahara Y., H. Hibasami, H. Katsuzaki, K. Imai and T. Komiya, 2001. Sesamolin from sesame seed inhibits proliferation by inducing apoptosis in human lymphoid leukemia Molt 4B cells. Internat. J. Molec. Med., 7: 369-371.

Mousa, M. A. A. and M. F. Mohamed, 2009. Enhanced yield and quality of onion (Allium cepa L. cv Giza 6) produced using organic fertilization. Ass. Univ. Bull. Environ. Res., 12(1): 9-18.

Naeem, M., J. Iqbal and M. A. A. Bakhsh, 2006. Comparative study of inorganic fertilizers and organic manures on yield and yield components of mung bean (Vigna radiate L.). J. Agric. and Social Sci., 2: $227-229$.

Nareshchandra S. J., 2016. Evaluation of botanical extracts against thrips (Thrips tabaci lindeman) infesting garlic. M.Sc. Thesis, Hort. Entom., Navsari Agric. Univ., Navsari, Gujarat.

Nasiruddin, K. M., A. M. Farooque and M .A. Baten, 1993. Effect of potassium and sulphur on growth and yield of onion. Bangladesh J. Agril. Sci. 20 (1): 35-40.

Olsen, S. R and L. E. Sommers, 1982. Phosphorus In: Page, A.L., R.H. Miller and D.R. Keeney (Eds.). Methods of soil analysis. Part 2. Amr. Soc. Agron., Madison, WI, U.S.A., 403 - 430.

Osawa, T., M. Nagata, M. Namiki and Y. Fukuda, 1985. Sesamolinol, a novel antioxidant isolated from sesame seeds. Agric. Biol. Chem., 49:3351-3352.

Oyewole, C. I. and A. N. Oyewole, 2011. Crop production and the livestock industry, the interplay: A case study of poultry manure and crop production. Proceeding of the 16 th Annual Conference of ASAN pp: 124-127.

Palm, C.A; R. J. K. Myers and S. M. Nandwa, 1997. Combined use of organic and inorganic nutrient source for soil fertility maintenance and replenishment. In: Brush et al., (Eds.). Replenishing soil fertility in Africa. Special publication No.51. Wisconsin, USA. Pp. 193. 
Pamplona-Roger, G.D., 2001. Encyclopaedia of medicinal plants. MARPA Artes Graficas, Alfajarin, Zaragoza, Spain, pp 230 -233.

Pavela R., 2007. Possibilities of botanical insecticide exploitation in plant protection. Pest Technol., 1: 47-52

Shrestha, J; A. Chaudhary and D. Pokhrel, 2018. Application of nitrogen fertilizer in maize: a review. Peruvian Journal of Agronomy, 2 (2), 22-26.

Singh S, D. Kumar, B. S. Chandel and V. Singh, 2014. Effect of balanced fertilization on yield, nutrients uptake and economics of potato in alluvial soil. Indian J. Agron ${ }_{2}$ 59(3):451-454.

Suresh, K. D., G. Sneh, K. K. Krishn and C. M. Mool, 2004. Microbial biomass carbon and microbial activities of soils receiving chemical fertilizers and organic amendments. Archives Agronomy Soil Science 50: 641-647.

Uzun, B., C. Arslan and S. Furat, 2008. Variation in fatty acid com-positions, oil content and oil yield in germplasm collection of sesame (Sesamum indicum L.). J. Am. Oil Chem. Soc., 85, 1135-1142. https://doi.org/10.1007/s11746-008-1304-0

Venugopa G., S. H. K. Sharma, A. A. Qureshi, G.E.Ch. Vidya Sagar and M.H.V. Bhave, 2017. Effect of sulphur levels and poultry manure on crop performance of soybean (Glycine max L.). Int. J. Pure App. Biosci. 5 (4): 1599-1605.

Wanasundara, P.K.J.P.D. and F. Shahidi, 1998. Process-induced change in edible oils, Process-Induced Chemical Changes in Food, edited by F. Shahidi, C.T. Ho, and N.V. Chuyen, Plenum Publishers, New York, City, USA, pp. 135-160.

$\mathrm{Xu}, \mathrm{J} ., \mathrm{S}$. Chen and Q. Hu, 2005. Antioxidant activity of brown pigment and extracts from black sesame seed (Sesamum indicum L). Food Chemistry, 91, 79

Yoldas, F., S. Ceylan and N. Mordogan, 2020. Residual effect of organic manure and recommended NPK fertilizer on yield and bulb performance of onion (Allium cepa L.) as second crop under greenhouse conditions. App. Ecol. and Env. Res., 18(1):303-314.

Zaman M. S., M. A. hashem, M. jahiruddin and M. A. Rahim, 2011. Effect of sulphur fertilization on the growth and yield of garlic (Allium sativum L.). Bangladesh J. Agril. Res. 36(4): 647-656. 